Geology of Mills and Fremont Counties

$$
\text { BY }
$$

J. A, UDDEN. 


\title{
GEOLOGY OF MILLS AND FREMONT COUNTIES
}

\author{
BY J. A. UDDEN.
}

\section{CONTENTS.}

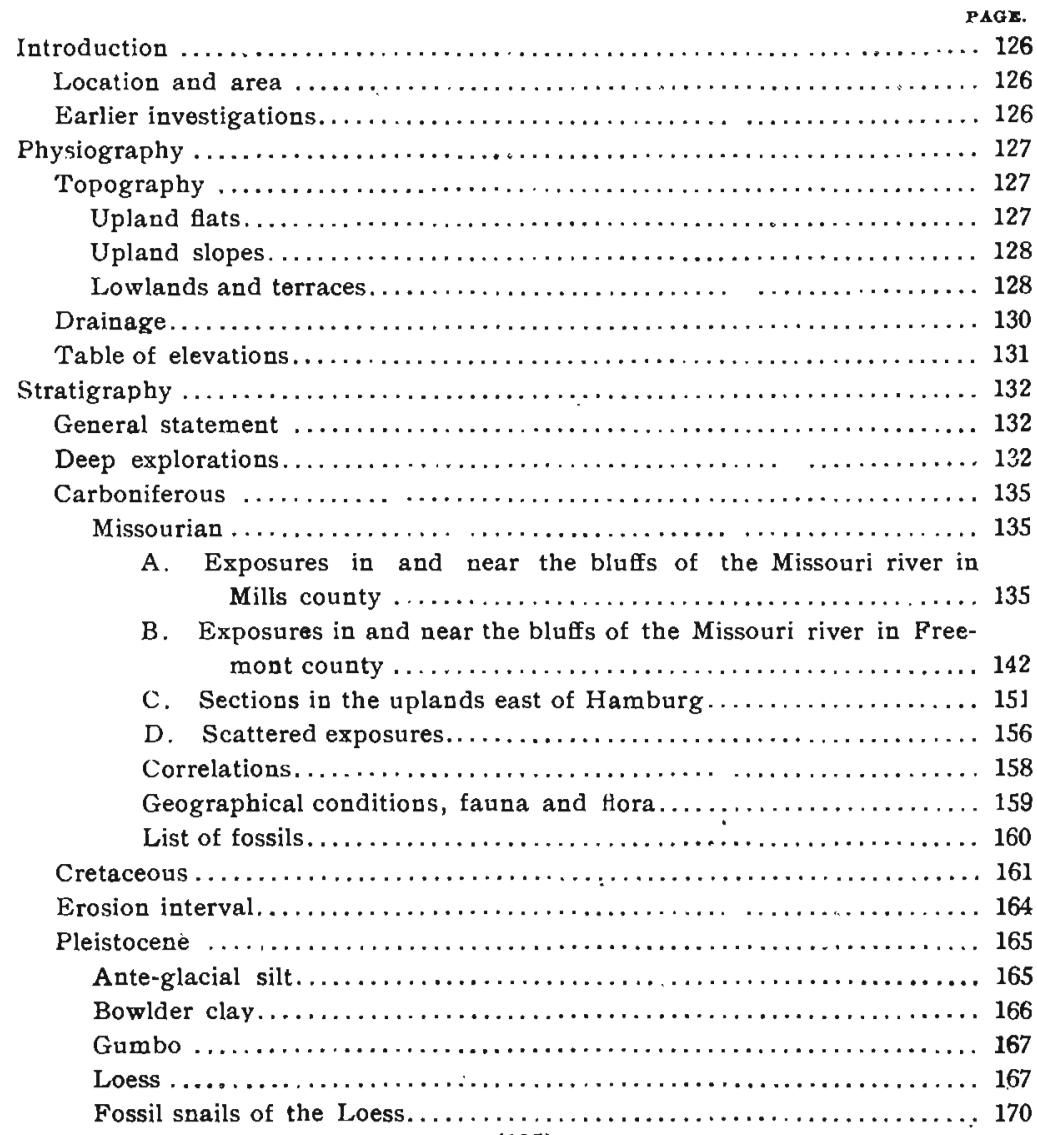

(125) 


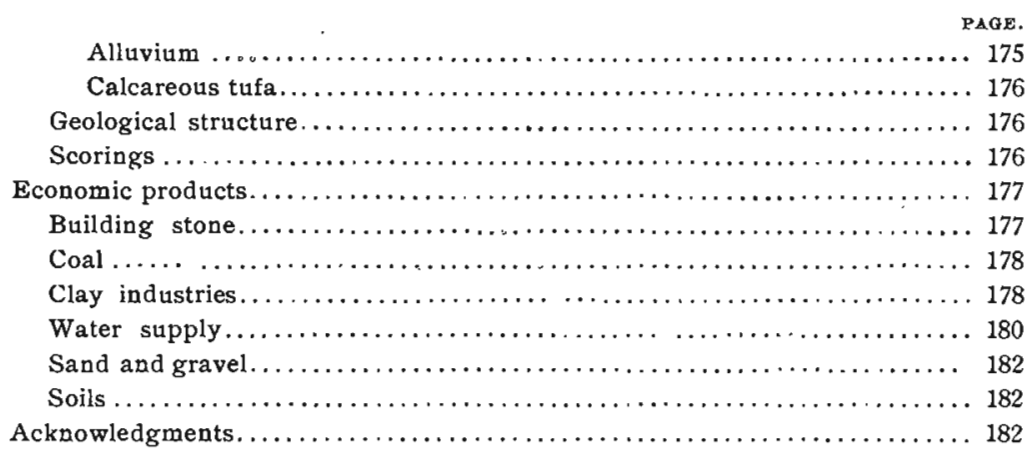

INTRODUCTION.

LOCATION AND AREA.

Fremont and Mills are the two southernmost counties in the tier abutting on the Missouri river. Together they form a rectangle bounded' by straight sides on the north, east, and south, and by the meanders of the Missouri river on the west, extending a little more than forty-one miles from north to south, and varying in width from nineteen to twenty-six and a half miles from east to west. They have an area of about 974 square miles, Fremont embracing about 524 square miles and Mills about 450 . Owing to changes in the meanders of the Missouri the area is constantly varying.

EARLIER INVESTIGATIONS.

Prof: C. A. White visited these counties in 1866. He was then state geologist of Iowa, and his observations were published in his First Annual Report in 1868, and also in his Geology of Iowa in 1870.*

Brief notices of the Coal Measures of these counties are given by Keyes in his Coal Deposits of Iowa.t

Prof. W. H. Norton bas published a record of the Glenwood artesian boring+ and Mr. Seth Dean has secured other data on the flow and the temperatures of the wells at this place.**

"C. A. White, First Annual Report, State Geologist, 1808, pp. 54-59; C. A. White, Geology of Iowa. Vol. I, pp. 358-382, and pp. 367-571.

tC. R. Keyes, Iowa Geological Survey, Vol. II, p. 443 and pp. 452 and 468.

IW. H. Norton, Iowa Geological Survey, Vol. VI, pp. 340-347. 
Finally Prof. .J. E. Todd, who for some time resided at Tabor, has made a number of observations on the drift of this region, and many of these are presented in his paper on The Moraines of Southwestern South Dakota and their Attendant Deposits. *

\section{PHYSIOGRAPHY.}

TOPOGRAPHY.

The principal topographic features to be noted in these counties are: The upland flats and ridges, the upland slopes, and the lowlands and terraces.

The Upland Flats and Ridges. The uplands consist of an old drift plain, modified by erosion and by the deposition on its surface of a blanket of loess. But little is left of the old surface of the flat drift plain. The only remnants left are some flat strips of land on the highest divides farthest away from the largest streams. These strips are usually less than one-fourth of a mile in width, often much less. The widest flats seen were between the headwaters of Mill creek and Rock creek in Locust Grove township in Fremont county; in the vicinity of the town of 'Tabor; on the divide between Mud' creek and Silver creek southeast of Silver City; on the divides north of Glenwood, north of Emerson and north and south of Hillsdale. The total area of these upland strips do not cover more than at most a few square miles of land in the two counties.

Excepting these flat areas the divides everywhere consist of ridges, more or less convex in cross section. These are broad'est farthest away from the principal drainage basins and as we approach the margins of the uplands they become more and more contracted and narrow. In the bluffs of the Missouri they are frequently only three or four feet icross, with a steep slope on either side. The average elevation of these summits of the uplands for the two counties is about 1170 feet above sea level, and it varies a hundred feet above and below this figure. The eastern two-thirds of the uplands in this area fall about thirty or fifty feet below: the average, while the highest divides apiproaching the Misisouri river bluffs rise above it in places as

*J. E. Todd; Bull. U. S. Geol. Survey, No. 158, pp. 89, 80, ete. 
much as ninety feet. From north to south they have a general descent of about a foot and one-third to the mile.

The Upland Slopes. By far the greater area of the uplands is formed of slopes which extend on either side from the creeks and ravines up to the crests of the ridges and flats on the divides. Farthest away from the larger drainage lines these slopes have a gentle grade and even near some of the larger creeks they may be a half mile in length and 100 or 125 feet in height. But near the Missouri bottoms they become more steep and frequently rise at a high angle to 150 or even 200 feet above the bottoms. Along these bluffs they are sometimes too steep to be tilled. Elsewhere they constitute the main farm land in the region. The distance from the foot of the lowest to the top of the highest slopes embraces a vertical range of about 360 feet.

The Lowlands and Terraces.-The principal lowlands are the bottoms along the Missouri river. These vary from one to seven miles in width on the Iowa side of the great river. They have an average elevation of about twenty feet above low. water and an average descent to the south of about one and one-third of a foot per mile, their general slope being about the same as that of the upland's. In the reentrant bends of the river bluffs, where the bottoms extend into the uplands, as they do to the southeast of Pacific Junction, north of Thurman, and again south of Knox, they rise as much as thirty or forty feet with a long gentle slope toward the bluffs. Otherwise they present an even plain with a few low tracts marking the former meanders of the river, such as Buckingham lake and Lake Wabonsie.

The lowlands of the West Nishnabotna have a pitch to the south of a little more than three feet per mile and a width increasing from one and three-fourths of a mile near the north boundary of Mills county to three miles in Prairie and Sidney townships in Fremont county. The pitch of the East Nishnabotna battoms is a little greater, nearly four feet per mile, and their width from bluff to bluff averages about two and threefourth miles. Near Riverton this valley is abruptly contracted to less than one mile. The valley of the united streams below Riverton in the same way abruptly narrows at the north boundary of Madison township to less than one mile. The cause of 
biank pare trecina $p \cdot 12-Y, 13)$

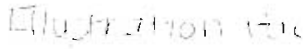
(2) $27,(12)$ 


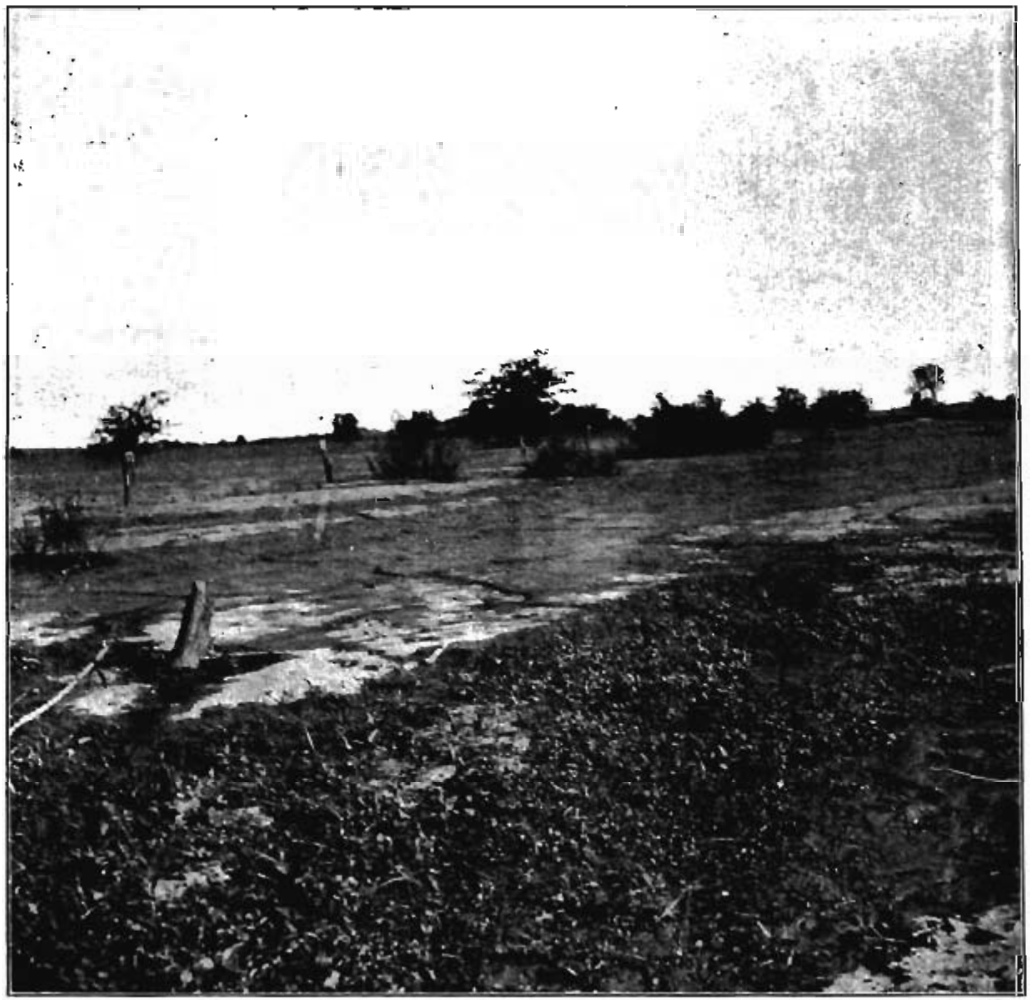

Deposit of mud after a flood on the Nishnabotna bottoms in section 19, Riverton township, Fremont cointy. 
such abrupt changes in the width of these lowlands is a rise of the bed rock which has impeded the erosive work of the streams in widening their flood plains, owing to the greater hardness of the materials encountered.

Other creeks with definite flood plains are as given below:

\begin{tabular}{|c|c|c|}
\hline CREEKS. & $\begin{array}{c}\text { AVERAGE WIDTH } \\
\text { OF BOTTOMS IN } \\
\text { MILES. }\end{array}$ & $\begin{array}{l}\text { SLOPE, FEET } \\
\text { PER MILE. }\end{array}$ \\
\hline 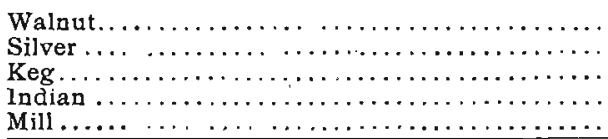 & $\begin{array}{l}.9 \\
.8 \\
.6 \\
.4 \\
.3\end{array}$ & 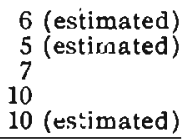 \\
\hline
\end{tabular}

The bottoms of Silver, Keg, and Mill creeks are all somewhat contracted in their lower course on account of encountering the bed rock, but their change in this respect is not as marked as in the case of the Nishnabotna rivers. Just below Malvern the Silver creek bottoms narrow to only a quarter of a mile for ir short distance and at Glenwood, Keg cheek can hardly be said to have a flood plain. The difference is less marked in the width of the flood plain in the upper and the lower course of Mill creek south of Riverton, but in each of these places bed rock is absent above and appears in the heds of the streams at the narrow places.

No notable terraces are to be seen on the flood plain of the Missouri river, but there are a few shelves in the bordiering bluffs near the streams which come from the uplands. One of these is seen on the south side of Wabonsie creek, having an elevation of about fifty feet above the bottom, and there are others less distinctly marked in the creeks farther south. On the bottoms of the two Nishnabatna rivers terraces are much more frequent. One which has an elevation of about fifty feet covers the north half of section 26 and thie south half of section 23 in Madison township, Fremont county. Another about forty feet liigh covers the east half of section $6, T$ p. $68 \mathrm{~N}$., R. XLT W. For three miles south of Randolph the same bench runs along the east bluff of the valley extending about a mile to the west. Again the same terrace covers about three sections of landl west of White Cloud, and there are smaller remnants farther to the north but 
on the same side, as in sections 12,13 and 14 northwest of Hastings, in sections 19 and 20 and in sections 8,9 and 4 in Tp. $73 \mathrm{~N}$., R. XLI W.

In these counties, as in Pottawattamie*, the bluffs of the Nishnabotna run in a series of loops somewhat less than a mile wide "with their concavities facing the river." The loops are separated by narrow spurs of upland, which intervene and project sometimes balf a mile into the valley. It is quite evident that the recesses are due to undercutting by the river and that the curves correspond to the meanders of the stream. As the loops have a radius much greater than the meanders of the present stream it is to be inferred that at the time they were made the river was considerably larger than at present. This may have been coincident with a glacial advance occurring farther north, after the deposition of the drift in this region. ' Loops of the kind are seen on both sides of the river between Henderson and Hastings to the northwest of Randolph, to the southeast of Siduey, and east of Hamburg.

DRAINAGE.

But little need be said regarding the drainage of the two coun. ties. It differs in no essential from that of the surrounding region. It has reached a stage of high maturity, as may be inferred from the nature of the topography. Drainage by seepage through the porous soil is remarkably efficient everywhere, but during heavy rains there is a prompt run-off from the surface on all slopes. Only a single instance of stagnant drainage on the upland has been noted, and this consists of a small tract on section 36, 'Tp. 68 N., R. XL W., where a swamp like condtion prevailed at the time of the making of the government surveys. With the general lowering of the level of ground water this has now disappeared. The effectiveness of seep drainage is especially evident on the terraces in the Nishnabotna valley, as to the west of White Cloud, where the surface of the terrace covers an arear of three square miles which is perfectly flat and yet remains uninvaded by drainage trenches, although the river, since their making, has had time to remove all but a small fraction of the old flood plain.

\footnotetext{
*Iowa Geol. Surv., Vol. Xr, pp. 205-206.
} 
Blank pege facing

$1,130 \quad(v, 13)$

rllustration:

Fic

Plate $V(v \cdot 13$ 


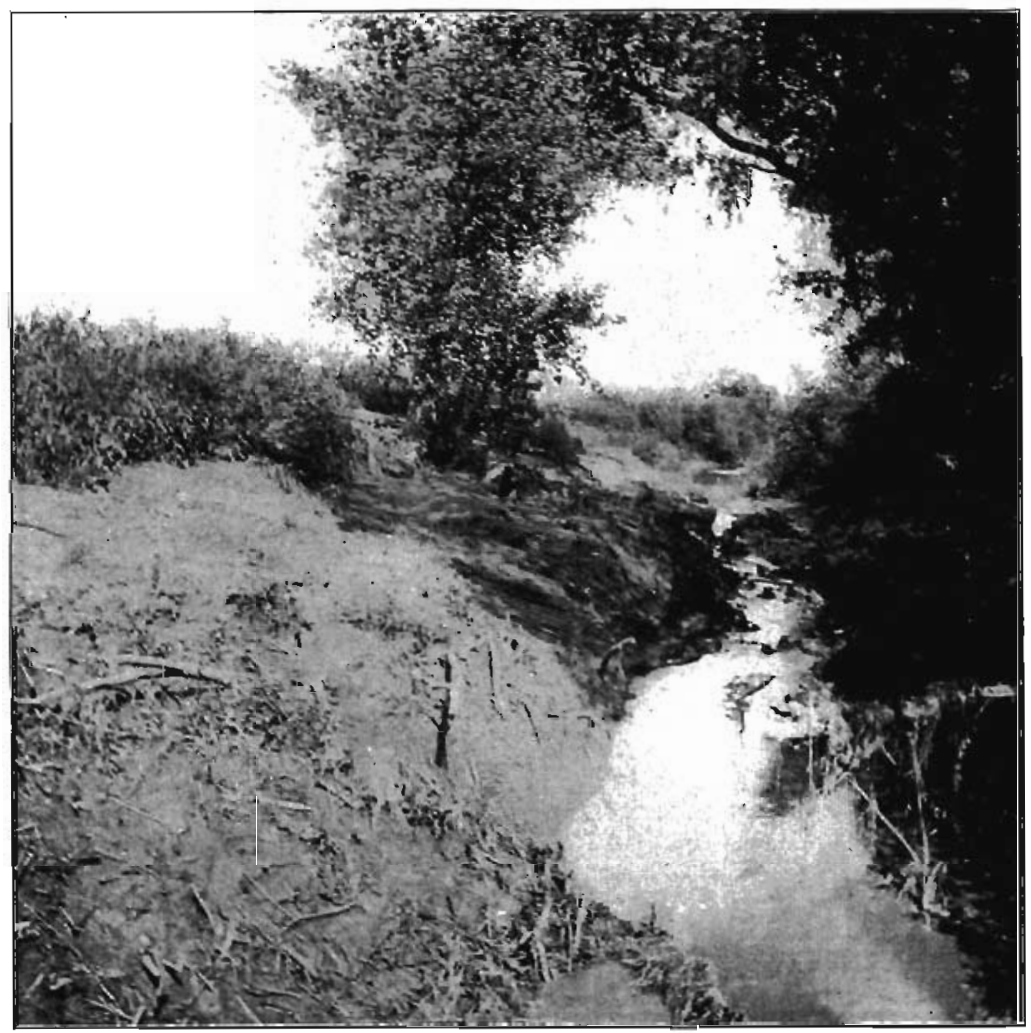

Deposit of mud and debris after a high flood in a tributary of Keg creek northeast of Glenwood. 
IOWA Geological SuRvey.

Piatev.

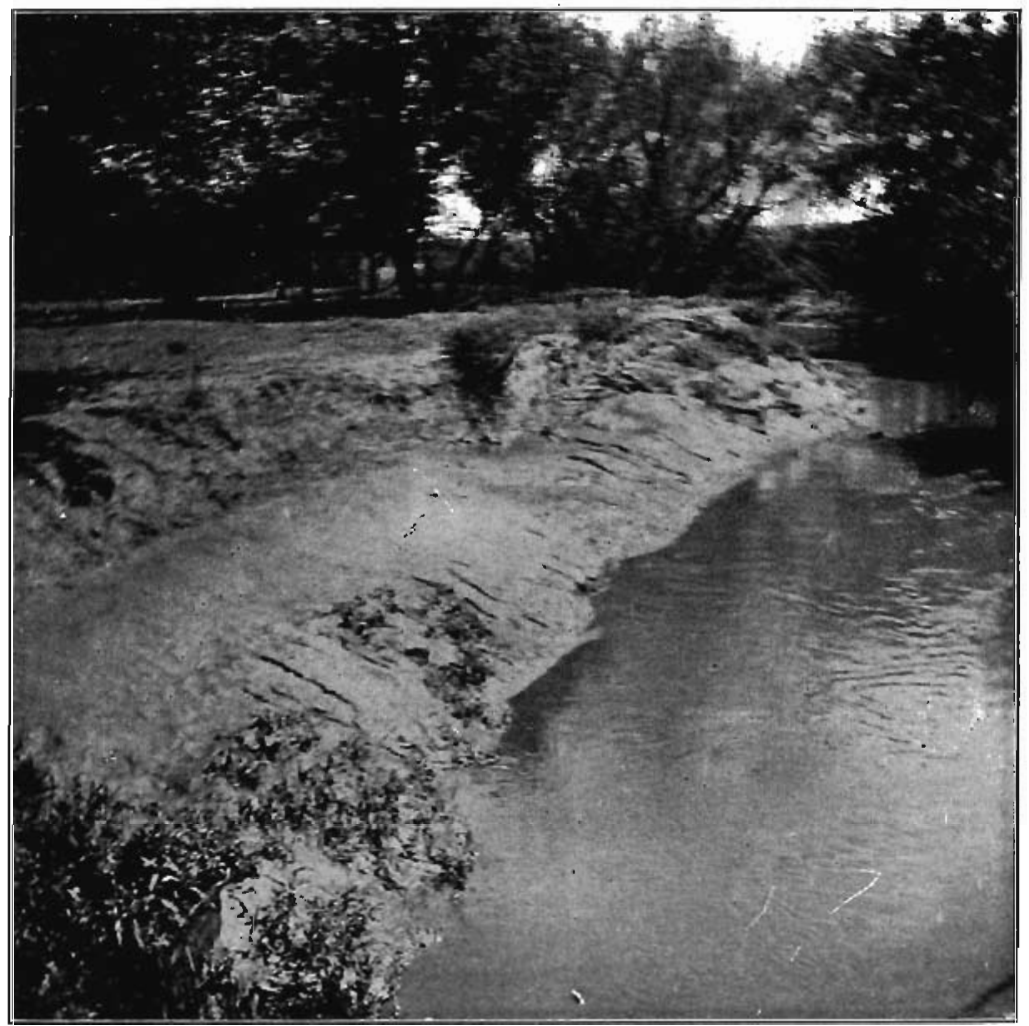

Dejn it of mud on the bank of the channel of Keg creek, west of Minneola, after high water. 
Blank pane tacing

p. $131(v, 13)$

Gilustation Fachij

plate IV $(v, 3)$ 
The drainage of the flood plains is in one respect less perfect now than before the prairies were under cultivation. With the general destruction of the native sod the slopes now more promptly shed the surface flow during rains and these easily gather a full load of silty sediment which impedes the run-off in the creeks and fills their channels. The mud can be seen settling: on the sides and the bottom of the channel, which thus becomes too small and causess the streams to overflow: their banks. The retention of the streams within their banks during floods is thus with every year becoming a more and more serious problem to agriculture. During the summer of 1902 hundreds of acres were flooded and covered with silt on the Missouri and the Nishnabotna bottoms, in places to a depth of as much as three feet. From some measurements which were made on the quantity of sediments carried by $\mathrm{Keg}$ creek during a freshet, it was found that the ratio of sedments to the water by weight was 1:44, that is, the water contains about 2.2 per cent of mud.

TABLE OF ELEVATIONS.

\begin{tabular}{|c|c|}
\hline LOCATION. & ELEVATION. \\
\hline 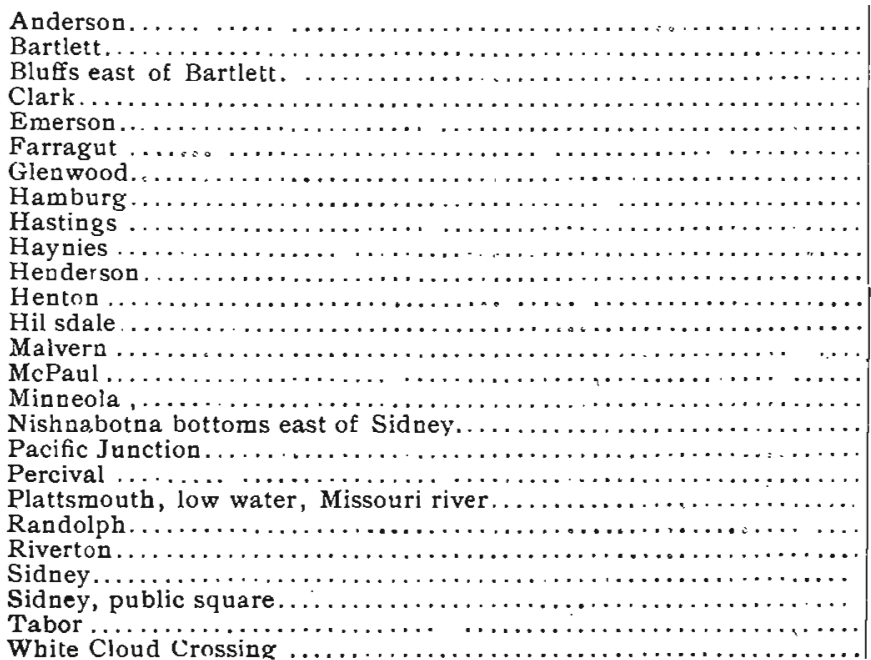 & $\begin{array}{c}966^{*} \\
946 \\
1190^{*} \\
1000^{*} \\
1053 \\
961 \\
981 \\
903 \\
999^{*} \\
954 \\
1031^{*} \\
963 \\
1189 \\
995 \\
927 \\
1036^{*} \\
915^{*} \\
958 \\
927 \\
940 \\
967^{*} \\
927 \\
1025 ? \\
1156^{*} \\
1240^{*} \\
973^{*}\end{array}$ \\
\hline
\end{tabular}

- Estlmates from anerold mensurements. The other figares are from Gannet's Dictionary of Altitudes and refer to elevation of ralload track at the depot. 
STRATIGRAPHY.

GENERAL STATEMENT.

The bed rock in this region is for the most part concealed under a heavy drift sheet. The best expasures occur in the bluffs of the Missouri river and in the vicinity of Hamburg and Riverton. The oldest rocks belong to the Upper Coal Measure series. Resting on these are some remnants of Cretaceous beds, and over all lies the drift. 'The general relations of these divisions are indicated in the following table:

\begin{tabular}{|c|c|c|c|}
\hline GROUP. & SXSTEM. & SERIES. & STAGE. \\
\hline \multirow[t]{2}{*}{ Cenozoic } & \multirow[t]{2}{*}{ Pleistocene. } & $\begin{array}{l}\text { Post-glacial } \\
\text { and Recent. }\end{array}$ & $\begin{array}{l}\text { Alluvium, loess and } \\
\text { terrace. }\end{array}$ \\
\hline & & Glacial. & Kansan and Pre-Kansan. \\
\hline Mesozoic. & Cretaceous. & Dakota. & Nishnabotna. \\
\hline Paleozoic. & Carboniferous & $\begin{array}{l}\text { Upper } \\
\text { Carboniferous. }\end{array}$ & Missourian. \\
\hline
\end{tabular}

\section{DEEP EXPLORATIONS.}

Some deep explorations have been made in each of the two counties. Seventeen years ago a boring was put down for coal at Riverton. It was made on the hill east of the village and extended down 700 feet. All that is now known about the nature of the ground is that it was mostly shale with some limestone and that there was a thin seam of coal at a depth of about 400 feet. On Mr. Rankin's farm on the northwest quarter of section 32 in Riverton township, sonth of Riverton, two wells have been made on the bottom lands in search of artesian water. Neither attempt was successful and the materials penetrated were mostly "soapstone," some dark shale and limestone.

At Hamburg: the Hamburg Fuel and Mining Company made a diamond drill hole to a depth of 1,000 feet in 1890. The hole was sunk near the east quarter post of the northeast quarter of seotion 21 , just outside the city limits where the ground has an 
elevation of 998 feet above the sea level. Most of the core was saved, but all labels have been lost and the depth of only one piece of the core is known with certainty. This is a fragment of compact gray limestone, apparently from the Coal Measures, which was taken at 800 feet from the surface. Some men who were interested in the drilling say that red shale was encountered at about 350 feet below the surface. There was a seam of coal about a foot thick at a depth of ninety feet and a very dark shale at about 650 feet. About 400 feet of the core can yet be seen, and of this fully three-fourths is limestone, all apparently from the Coal Measures. Several pieces have a fine oolitio structrue, resembling that seen in the old quarry near Crescent in Pottawattamie county. These ledges probably dip to the south and lie here at some distance below the surface. One fact which is established beyond a doubt by this drilling is that the terranes at this point contain at least some 300 feet of limestone in the first 1,000 feet. Whether all of this thickness belongs to the Coal Measures cannot be made out with ærtainty, but it seems likely that such is the case. No part of the core resembles the Lower Carboniferous.

In Mills county two deep wells have been sunk at Glerwood. Both were made by churn drills. Samples of the drillings from the city well have been collected by Mr. Seth Dean and described by Norton," who summarizes the formations as follows:

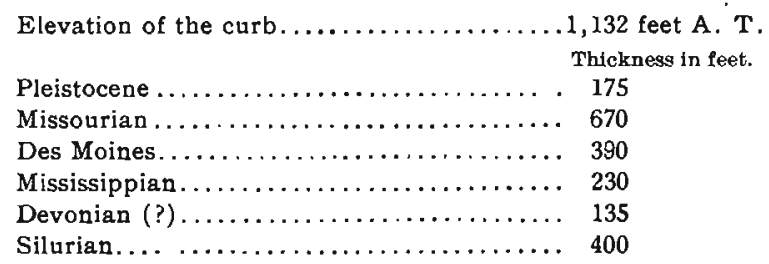

The Missourian in this well contained a considerable amount of limestone, as at Hamburg.

Some years later a well was made on the bottom land of Keg creek, in the south part of the city by the Institution for Feeble-Minded Children. The elevation of the curb is here

"Iowa Geol. Surv., Vol. VI. pp. 340-347. 
980 feet above sea level and the total depth of the well is 2,000 feet. A record was taken of the strata penetrated at the time the well was made and a copy of this record follows. Some discrepancies are apparent but there is a fair correspondence in the two wells.

RECORD OF THE STRATA PENETRATED IN THE BORING AT THE INSTITUTION FOR FEEBLE-MINDED CEULDREN AT GLENWOOD.

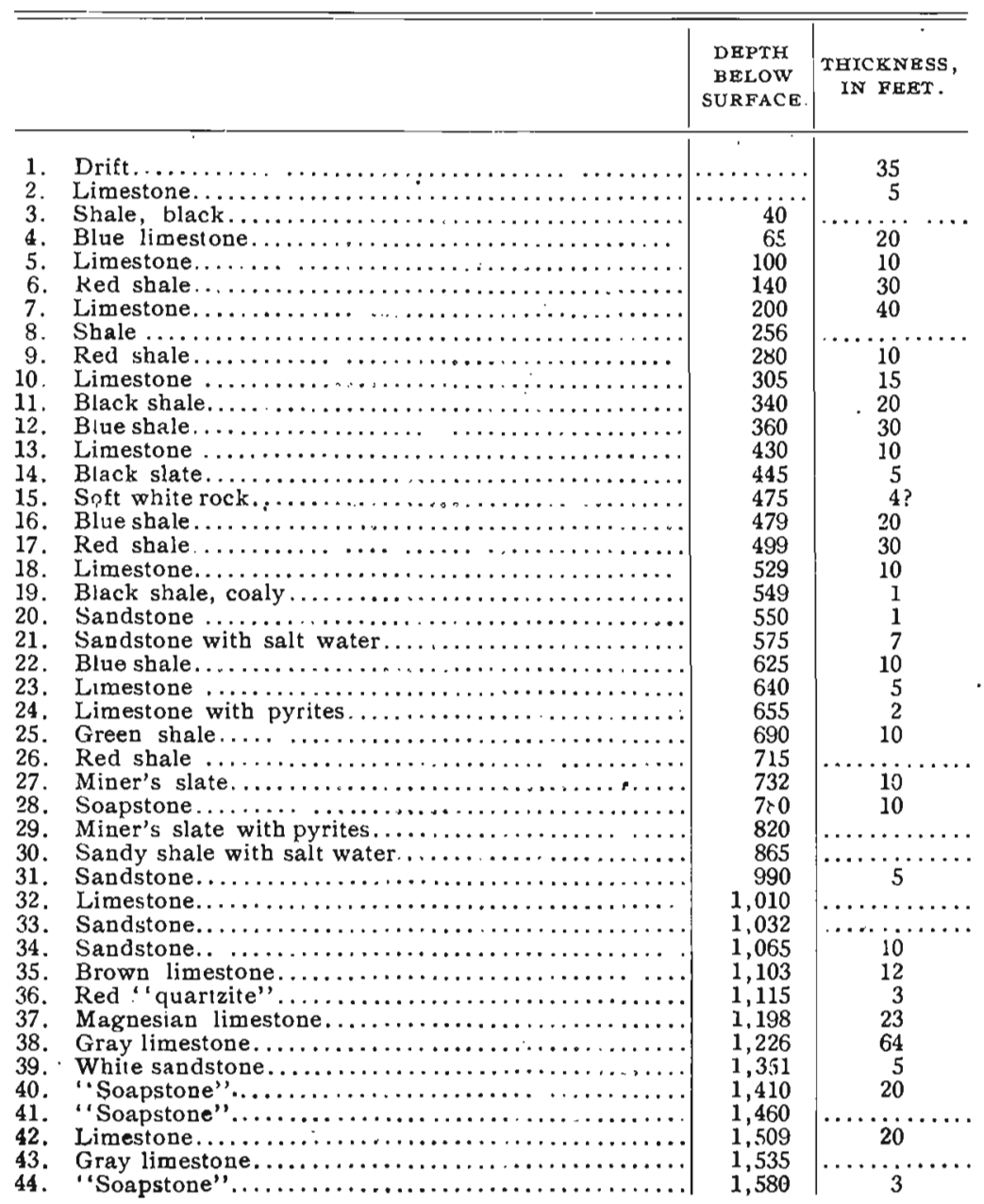




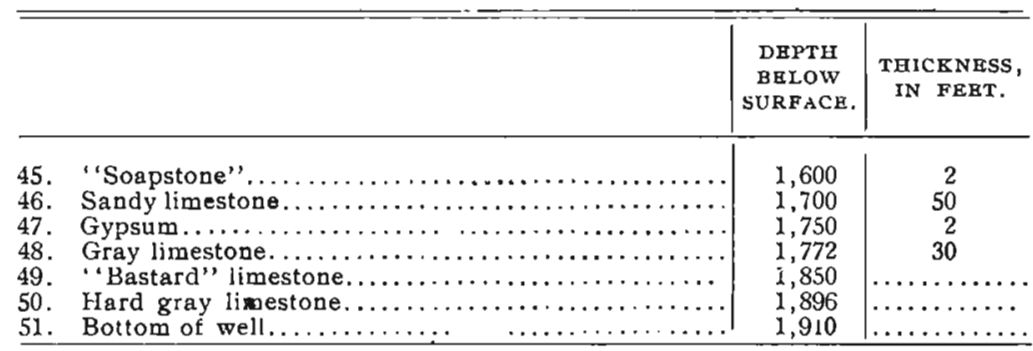

Gypsum occurred in the city well at depths corlesponding with No. 47 above, evidently in the same terrane, and in the one Norton regards as Silurian.

\section{CARBONIFEROUS SYSTEM.}

THE MISSISSIPPIAN.

The rocks of the Upper Coal Measures in these counties consisit of shales and limestones with some arenaceous beds and some marly clays. An account of their ocurrence and particular characters in different localities will be first introduced. The different localities of the exposures have been arranged in four groups as follows:

A. In and near the bluffs of the Missouri river in Mils county-sections I-VIr.

B. In and near the bluffs of the Missouri river in Fremont county-sections virI-xviII.

C. Sections in the uplands east of Hamburg-seotions XIXxxIII.

D. Scattered outcrops-sections XXIV-xxvi.

EXPOSURES IN AND NEAR THE BLUFFS OF THE MISSOURI RIVER, MILLS COUNTY.

I. SECTION IN THE QUARRY AT HENTON.

4. Gray shale, with thin calcareous layers and occasional. calcareous concretions from one to two inches in diameter. These concretions are compact in texture and contain some imbedded curving tubules one-fourth millimeter in diameter. Fossils: denticles of annelids, minute conical teeth, and a small productus................... 2 
TEET

3. Yellow or gray limestone............. $1 \frac{1 / 2}{2}$

2. Cream colored or gray limestone with kidneys of dark chert usually several inches in diameter. On a polished surface it is seen to hold scattered spheroidal oölitic grains from .5 to 2 millime'ers in diameter and some clean frngmeats of shells. These lie in a copious matrix of ill defined organic granules, averaging only about onetenth of the size of the ooliths, and these smaller granules are held together by a translucent, calcareous cement. The rock is cut by some thin fissures healed with calcite, and carrying in places small grains of iron pyrites. The chert is identical in texture with the rock........... 1

1. Light, bluish gray limestone in heavy ledges, with some shaly layers and with irregular nodules of chert. It is composed mainly of a copious matrix of fine, indistinct particles in which are imbedded occassional joints of crinoid stems, some large shell fragments which are sometimes clean and sometimes covered with an o"litic crust, and elliptical granules of oölitic aspect, about one and one-half millimeters in largest diameter. Between the lower courses in the quarry are shaly, dark and carbonaceous seams containing brachiopods, spines of crinoids, and spines of archæocidaris. In one of these seams there were some fucoid-like, flat, curving bodies ranging up to 8 inches in length, nearly 2 inches wide, and from one-fourth to three-fourths inch in thickness, elliptical in outline in cross-section. The surface of these, when etched and cleaned by rain, is seen to be strewn with black, smooth, shining and round needles of pyrites, of a diameter ranging from .02 to 1 millimeter in diameter and from 1 to 6 millimeters in length, or more, tapering slightly to one end. On crushing, grinding and washing the body of these stems, small and straight siliceous spicules were obtained, of somewhat rough outline, measuring about .02 millimeters in thickness. These have been identified by J.

M. Clark as sponge spicules.............. 3

From the different ledges in this quarry, but mostly from the lower courses, there were taken the following fossils: Archaeocidaris edgarensis, Erisocrinus typus, Eupachycrinus verrucosus, Fistulipora nodulifera, Rhombopora lepidodendroides, Ambocoelia planoconvexa, Chonetes granulifera, Derbya crassa, Pro- 
ductus cora, $P$. costatus, $P$. pertenuis, Seminula argentea, Spirifer cameratus, Allorisma subcuneatum, Chaenomya leavenworthensis, Ch. minnehaha, Solenomyn (?), Pinna peracuta, Beller. ophon (large), other gasteropods.

About one-half mile south of Henton there is a small quarry which has recently been worked in the base of the bluffs. The section is as follows:

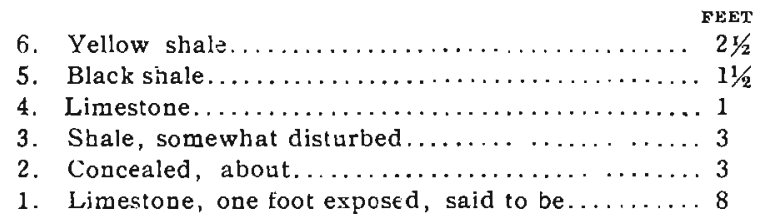

The upper four members have been exposed in exploring for coal. Another exploration was some time ago made east of this point, back of the bluff. This is reported as having penetrated much limestone, but there was no coal.

II. SECTION IN THE QUARRY NEAR THE MISSOURI BLUFFG AT MLLS STATION.

4. Yellow shale or disintegrated limestone containing Fusultna cylindrica.................... $2 \frac{1 / 2}{2}$

3. Limestone, decayed and yellow above, gray and

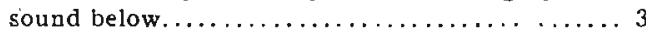

2. Concealed, probably shale................ 2

1. Bluish, dark gray limestone.............. 1

III. SECTION AT THE BIG SPRING IN EAST HALF OF SECTION I0, LXONS TOWNSHU, MILLS COUNTY.

4. Hard gray limestone.................. 2

3. Blue shale.. ......................... 2

2. Blue hard limestone.................... 1

1. Blue shale..........................

IV. SECTION IN THE BLUFFS SOUTHWEST OF THE CENTER OF SEOTION 10, LYONS TOWNSHIP, MULLS COUNTY.

7. Bluish gray shale

FEDT:

6. Dark limestone consisting of compact matrix containing clean organic fragments, especially spines of producti. There were also seen in a ground specimen vermicular extensions of concentrically and irregularly laminated calcareous material. Fossils: Ambocolia planoconvexa, Produclus sp.. 1/4

10 G R+p 
5. Blue shale $\ldots \ldots \ldots \ldots \ldots \ldots \ldots \ldots \ldots \ldots \ldots \ldots \ldots \ldots$

4. Blue limestone, in places yellowish and soft. The lower part containing Syntrielasma hemiplicata, Fusulina cylindrica and an Orthis (?) and clean organic fragments in a fine textured, fragmental

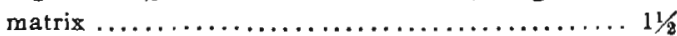

3. Arenaceous and micaceous silt with wel! marked joints, yellow above and bluish green below.' A sample consisted of well assorted quartz particles from one-eighth to one-thirty-second millimeter in diameter, free from finer silt. It apparently contained no fossils, large or small .............6 6

2. Greenish or bluish gray limestone in strong and massive ledges, for the most part made up of an unassorted mixture of oölitic grains from 5 to 4 millimeters in longest diameter and mostly clean organic fragments of all sizes, imbedded in a matrix of occasionally transparent but mostly more or less distinctly fragmental and granulated calcareous matrix. In places the rock is almost perfectly oölitic. There are a few thin seams of calcite. Fossils: Small gasteropods and bivalves, crinoid stems, Fistulipora nodulifera, Fusulina cylindrica. 2

1. Yellow shale $\ldots \ldots \ldots \ldots \ldots \ldots \ldots \ldots \ldots \ldots \ldots \ldots, \ldots \ldots$

Campophyllum torquinum occurs along the base of the outclop.

V. SECTION IN THE BLUFF' IN THE SE. 1/4 OF SEC. 16, LYONS TOW NSEIP, MILLS COUN'TY.

14. Limestone, ölitic above and compact below .......

13. Gray shale, with two calcareous stony layers respectively about three and one-half and four and onehalf feet from the upper surface. Fossils from the shale: Archaocideris (spines), Eupachycrinus verrucosus (plates), Scabpiocrinus sp. (plates) Fistulipora nodulifera, Polypora submarginata, Productus semireticulatus, $P$. nebraskensis, Derbya crassa, Spirifer cameratus, Choneles granulifera, Bellerophon carbonaria, Pleurotomaria, sp. Allorisina (?) sp. In one of the stony layers thers were abundant individuals of Productus nebraskensis and also Derbya crassa and some bryozoa, Chonetes granulifera, Discina convexa, Euompha- 
lus rugosus, Myalina subquadrata, Myalina recurviroslris (?), Edmondia sp., Aviculopeclen sp., Entolium aviculalum, Pseudomonotis hawni, Pinna (peracuta ?) ......................

12. Limestone ........................... 1

11. Marly gray shale, almost a limestone above. Fossils: Spines, plates and stem joints of crinoids. Fusulina cylindrica, Rhombopora lepidodendroides, Ambocalia planoconvexa, Chonetes vernuiliana, Produclus semireticulatus, Productus sp., Spiriferina cristata, Derbya crassus, denticles of anne-

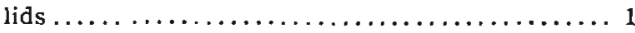

10. Limestone, with a band of chert...........13/4

9 . Shale, gray and black, consisting of slightly calcareous silt, in which have been found some small strcaks or pockets of coal. One of these contained a piece of fossil wood with fibro-vascular bundles resembling those of ferns. Other fossils: Seplopora biserialis (?), Ambocolia planoconvexa, Pugnax uta, Derbva crassa, Productus longispinus, Euomphalus rugosus (?), Schizodus (?), Aviculopecten (?), pygidium of a small Phillipsia and several denticles of annelids .............. 1 $1 / 2$

8. Compact white limestone in which a Fistulipora nodulifera was observed. It breaks preferably along vertical planes................... 1

7. A stratum of highly calcareous shale.......... $11 / 3$

6. Shale, slightly calcareous, containing occasional chitinous denticles.................... $2 / 3$

5. Gray limestone, fragmental, some of the fragments clean and some covered with an oölitic crust, all imbedded in a matrix of fine texture. Fossils: Fusulina cyindrica, Textularia (?). The upper four $i \vec{u}$ ches consist of a close matting of minute tubes of an Ammodiscus with the interstices filled with clear calcite $\ldots \ldots \ldots \ldots \ldots \ldots \ldots \ldots \ldots \ldots, 31 / 2$

4. Shaly limestone changing into rock like that in the next number ...........................

3. Strong heavy ledges of yellowish gray limestone separated by seams. The ledges vary from 8 to 14 inches in thickness and encroach upon each other by alternately thinning and thickening. A polished specimen showed some clean and a few incrusted organic fragments imbedded in a 
matrix of finer fragments and structureless calcareous material. Fossils: Fusulina cylindrica, Textularia (?), valves of small lamellibranchs and joints of crinoid stems. In the shaly seams there is a smaller amount of matrix which is also more argillaceous and the organic fragments, consisting of worn pieces ef shells, lie in a horizontal position. In these layers Seminula argenlea an 1 Pugnax ula were noted. Fusulina cylindrica is more abundant in the shaly seams than in the limestones ....................... 4

2. Concealed, probably in part containing a black, bi ghly fissile shale (?) . ................. 4

1. Bluish gray shale..................... 4

This section is seen extending along the bluffs for nearly one-half mile, where extensive quarrying was carried on for several years. The lower shale is not all seen at one place.

VI. SECTION EAST OF TEE CENTER OF SEC. 21, LYONS TOWN COUNTY.

12. Dark limestone full of shell fragments much weathered .............................. I

11. A light gray, calcareous silt with a small admixture of fine sand and of micascales. Fossils: Seminu/a argenlea (small and flattened), Derbya crassa and a Bellerophon (?) ................... 5

10. Gray limestone, friable and oölitic above, compact below. The oülitic sperules have a thick and rough crust and are quite unassorted as to size, varying from .2 to 3 millimeters in diameter. The matrix, which is sparse, also contains occasional clean organic fragments. A ground specimen of the lower part of the ledge was a white, soft and structureless mass, in which lay scattered indistinct minute organic fragments and occasional clean brachiopod spines. Fossils: Myalina recurvirostris and some brachiopod i..........

9. Marly white limestone, evidently made up of a fine calcareous saud........................

8. A gray shale with two thin bands of soft gray limestone about 3 and 4 feet from the top. This shale is somewhat variable in composition, being more calcareous at some levels than at others, and in places presenting a lumpy mixture of calcareous and argillacecus mud. The thin calcareous seams are quite structureless but contain occasional clean organic fragments, among which are some delicately marked tubules wi h whte walls. 
Fossils: Tex'ularia (?), joints of crinoid stems, plates of Scaphiocrinus hemisphericus, Fistulisora nodulilera, Polyopora, sp., Rhombopora lepidodendroides, Productus longispinus, P.prattenianus, $P$. nebraskensis, Choneles granulifera, Dirbya crassa, Myalina subquadrata, Schizotus sp. Fossils are esfecially abundant in the calcareous layers which contained a Myalina reckroirostris and also an Edmondia.................... 10

7. Compact, fine-grained, gray limestone, with a six inch layer of gray chert in the lower part. 'The limestone contains fragments of crinoid stems, shells and skeletons of bryozoa imbedded in a copious, almost strictureless matrix. The rock in contact with the chert is a dolomite, apparently of the same texture as the limestone, but when examined under the microscope it is seen to be composed of small crystals. The dolomitization was evidently effected by the same conditions that segregated the siliceous material into chert. The latter exhibits the same texture as the limestone in which it lies................. $21 / 2$

6. Gray, marly shale with a three inch layer of limestone. The upper part of this stratum is mostly calcareous, impalpable mud with scattered crinoid joints and fragments of shells. Fossils: Fusulina cylindrica, stems and plates of crinoids, Rhombopora lepidodendroides, Derbva crassa. Spiriferina cristata, Productus (small), Ambocalia p!anoconvexa, Chonetes vernuiliana ................... 1/ 12

5. Calcareous, gray shale, or marl, like the above but more clayey and containing chitinous denticles and Ammodiscus and other rhizopod foraminifer remains $\ldots \ldots \ldots \ldots \ldots \ldots \ldots \ldots \ldots \ldots \ldots \ldots$

4. Black coaly shale only slightly calcareous and consisting for the most part of a fine clayey silt. Fine sand is almost absent. Fossils: denticles of different kinds.................. $1 / s$

3. Compact, grayish white limestone of fine texture and having tendency to break along vertical planes. A polished specimen shows some minute organic fragments scattered through an almost structureless ca'careous matrix. Streaks of travertinelik a calcite occur in irregular pockets one or two inches in length. Fossils: small spires of gasteropods and Textularia (?).............. 1/3

2. A calcareous sha'e, black abova and yellow below.. 1

1. A light gray linestone in strong ledges. A ground specimen from the upper part was seen to be 
partly made up of rather imperfect oölitic spherules. These consist of rounded organic fragments, which have become encrusted by a thin calcareous deposit. Their sizes range from .3 to 2 millimeters in diameter. Some are flat. The matrix is in part clear, translucent calcite and in part a white, opaque, and structureless mass. A part of the specimen lacked the oölitic granules and was made up almost wholly from a mitrix showing indistinct organic particles, and holding a few bits of shells. Small fissures and irregular cavities filled with clear calcite were frequent. Fossils: Fusulina cylindrica, Pinna sp. and spires of small gasteropods................ 4

The above exposure is in an old quarry where the lowermost ledges are now covered with debris and cannot be seen. The section is the same as the previous one, but includes two additional numbers above, and does not reach as far down.

VI. SECTION IN TAE BLUFFS NEAR THE OENTER OF THE SW 1/4 OF SEC. 27 , LYONS TOWNSHIP, MILLS COUNTY.

4. Disintegrated, shaly limestone............. $18 \ldots$.

3. Limestone with some unassorted oülitic spherules.. $2 \frac{1}{2}$

2. White marly shale with imbedded organic fragments. Fossils: Fusulina cylindrica, a small cyathophylloid (worn), plates of Archæocidaris, Rhombopora lepidodendroides, Spirifer? (small), Ambocalia planoconvexa, Choneles, sp........ 2

1. Compact gray limestone with imbedded organic fragments of small size.................... 2

EXPOSURES IN AND NEAR THE BLUFFS OF THE MISSOURI RIVER, FREMONT COUNTYY.

VII. SEOTION IN THE BASE OF THE BLUFFS NEAR THE OENTER OF SEC. 14, SOOTT TUWNSEIP, FREMONT COUNTY.

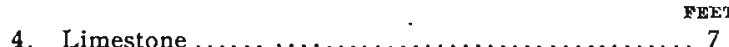

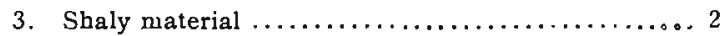

2. Marly shale with numerous specimens of Derbya crassa and also Productus nebraskensis, $P$. cora

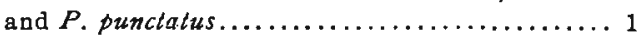

1. Shaly material $\ldots \ldots \ldots \ldots \ldots \ldots \ldots \ldots \ldots \ldots \ldots \ldots, 4$

Occasional small outcrops appear north of this place and to the south they are frequent. The next section is at a 
point about a half mile farther șouth, where there is an old prospect pit for coal a short distance to the south of the north end of Wabonsie lake.

IX. SECTIONIIN THE BLUFF NEAR THE SOUTH LINE OF SEC. 14, SCOTT TOWNSHIP, FREMONT COUNTY.

8. Limestone of minutely oölitic texture ........... 3

7. Impure limestone containing spines and a jaw plate of Archæocidaris, a small cyathophylloid coral, Fusulina cylindrica, Chonetes granulifera, Spirifer cameratus and Seminula argentea.......... 21/2

6. A gray limestone in strong and massive ledges containing crinoid stems and sparsely studded with fossil fragments. There are also fissure-like pockets filled with travertine-like, irregularly laminated, calcareous material. These ledges are separated by thin shaly seams (best seen at 3 and 4 feet from the top of the number) containing many Fusulina cylindrica ...................11

5. Giay limestone with more frequent fossils........ 1/2

4 Gray shale with bands of black shale containing some lamellibranchs, Produclus nebraskensis (?) and an Orbiculoidea (?). Vermicular extensions of blue shale project into the dark bands........ 11/2

3. Bluish limestone with occasional crinoid stems ..... I

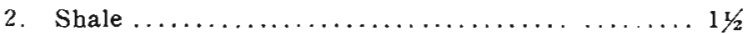

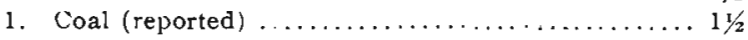
Fire clay...$\ldots \ldots \ldots \ldots \ldots \ldots \ldots \ldots \ldots$ ?

In section 23 southeast of Lake Wabonsie, there is rock in the bluffs almost the entire distance, owing no doubt to comparatively recent undercutting of the upland by the river where it followed the channel in which the lake or slough has since formed. It was thought best to unite all the outcrops into one section as there was no difficulty in referring them to their right position relative to each other. Numbers 1 and 13 are both best exposed near the southwest corner of the section, the former in an old quarry. The same outcrops have been described by Prof. C. A. White* at an earlier time when the beds were better exposed by quarrying. His section gives a greater thickness' to the lowest limestone, and in addition about eleven feet of shale, thin limestone and sandstone which were then exposed.

* Geol. of Iown, C. A. White, 1870, pp. 353-850. 
X. GENERAL SECTION IN THE BLUFF IN SEC. 23. SCOTT TOWNSHIP, FREMONT COUNTY.

13. Dark bluish gray, almost black, limestone with some irregular seams of sandy material and occasional siruous accretions of black chert. A band specimen was seen to consist of a matrix of fine but blotchy and variable texture, finer where holding most fossil fragments and coarser where these are absent: In this matrix are clean and unworn fragments of unassorted sizes of shells, crinoid joints, spines of brachiopods, small bivalves and gasteropods. There are also occasional minute grains of pyrites and of siliceous material. Fossils: Septopora biserialis, Fenestella (?), Rhombopora lepidodendroides, Cythere (frequent) and Productus longispinus (?) ................... 21/2

12. Shale, gray or almost black above and yellow below. Contains many fossils near the middle. In the lower part there are round, yellow, calcareous concretions. The bulk of a hand specimen was seen to consist of a rather well assorted silt of quartz grains, free from clay. It contained thin flakes of organic shells, minute chitinous organic fragments. The fossils are mostly distorted specimens of Productus. Myalina, Derbya crassa and Seminula argentea...................... 5

I1. A somewhat disintegrated and soft, yellow, oölitic limestone of unique aspect. Two hand specimens were seen to differ chiefly in the quantity of the matrix, scanty in one and copious in the other. The matrix is compact and in places semitransparent. The oölitic spherules are unassorted, ranging in size from 1 to 3 millimeters in diameter, The larger ones especially, have a rough surface and are generally elongated and elliptical in longitudinal section, and also flattened. They mostly have a flat shell fragment for a center and this is covered by a thick deposit of irregular, wrinkled, concentric calcareous layers, rather soft. Some were seen to have been fissured as by pressure, the fissures being healed with calcite. Some dark sphcrules were also noted, resembling organic fragments. The matrix also held unworn and clean shell fragments and small spires of gasteropods. The mass is cut by minute, healed fissures............................. 1

10. Grray limestone in a single strong ledge, with here and there crevice-like extensions of crystalline and travertine-like calcareous material. A ground 
specimen was seen to consist of an agglomeration of organic fragments of two sizes. The larger ones range from 1 to 20 millimeters in diameter and are surrounded by a tufaceous crust of soft calcareous material of light color. These lie in all attitudes in a copious matrix of smaller encrusted organic particles averaging .2 millimeters in diameter. Bryozoa and joints of crinsid stem; were noted........................... $31 / 2$

9. Gray calcareous shale with many fossils, such as: Rhombspora lepidodendroides, other bryozoa, Archceociduris aculeala, plates of Scaphiocrinus (?) and Zeacrinus (?) joints of crinoid stems, Spirifer cameratus, Dielasma bovidens, Ambocalia planoconvexa, Choneles granulifera, Durbya crassa, Produclus punclatus, $P$. semireliculalis, $P$. nebraskensis, $P$. pratlenianus, $P$. perlenuis, Myalina subquadrata, Edmondia nebraskensis (?), Allorisma subcuneala, Nucula beyrichia (?), Modiola subelliplica (?), Aviculopecten, sp., Schizodus (?), Euomphalus rugosus, Bellerophon carbonaria, Murchlsonia, sp., Cylhere, sp. About seven feet below the top of this shale is a ledge of limestone one foot thick. This contained a flat fish tooth. A ground specimen of this ledge was made up of a spare matrix of translucent calcite, in which were imbedded numerous minute but delicately marked tubular bodies of varying length and shape ranging from less than .I to .2 millimeters in diameter, some being rounded and short so as to resemble oölitic grains. There are also lärger rounded and incrusted flat organic fragments, some of very dark color, as well as some clean thin shell fragments, and entire small brachiopuds and gasteropods.............11

8. Limestone, with some shale, not well exposed. ...3

7. Light gray marl with quartz particles of small size When washed it yields fragments of echinoderms such as spines of Eocidaris halliana, joints of crinoid stems, spines of various echinoderms and brachiopods, chitinous denticles and Cythere .... 1

6 Gray, compact limestone in a single ledge, which has a decided tendency to break along vertical joints A ground specimen is seen to consist of a matrix of minute, ill-defined, calcareous particles or mud and in this are imbedded a few large scattered clean and angular organic fragments. Thero are occasional cavities and fissures filled with calcite, often laminated like travertine. Fossils: spires. 
of small gasteropods and Rhombopora lepidodendroides.............................. $2 / 3$

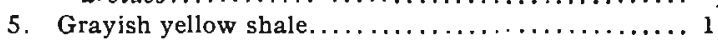

4 A solid ledge of yellowish gray limestone. A ground specimen is seen to be made up of flat, rounded, organic fragments mostly from 1 to 2 millimeters in diameter lying in a horizontal position. There is hardly any matrix but the fragments are covered by an oölitic crust. Fossils occasionally seen: Bryozoa, small spires of gasteropods and joints of crinoid stems ......... 31/8

3. Ash gray, shaly marl or limestone, yellow below, weathering into flat chips. A lump hard enough to be ground consisted of a marly, dark gray and soft matrix, with scattered clean organic fragments, and occasional small grains of quartz. Fossils noted: Fusulina cylindrica (gibbous), bryozoa, Ambocelia planoconiexa, Axophyllum rude. (?) spines, body plates and jaw plates of Archæocidaris, and a foraminifer............ 2

2. Strong, yellowish gray limestone, consisting of a copious mass of finely fragmental matrix holding a few scattered, rather large shell fragments and occasional fusulinas...................

1. Solid ledges, from 4 to 10 inches thick, of a gray limestone, the ledges running in irregul rly wavy courses.............................

XI. SECTION IN A RAVINE IN THE NW. 1/4 OF THE SW. $1 / 4$ OF S: C :3, SCOTT TOWNSEIP, FREMONT COUNTY.

16. Dark gray, rather hard limestone, weathering brown. A polisbed specimen was seen to consist of clean shell fragments from 2 to 3 or 4 millimeters in diameter, scattered in clusters in a matrix which was partly transparent. This matrix also contains tubular bodies that appear like rings in cross section, 1 millimeter in diameler or less, delicately marked. Occasionally cross sections of several contiguous individuals appear like a chain. Fossi s: Derbya crassa, Fusulina cylindrica, Myalina recurviroslris and some bryozoa. The rock also contains horizontally placed plates about 2 millimeters thick of vertical prismatic or fibrous structure. The material in these plates is calcite, highly bituminous and of brown color. Each prism shows delicate straight lines transverse to the axis of the prism. The 'ges of these plates are square. They are probably of organic origin, as fragments of some broken shells...... 3 
TEET

15. Concealed (shale, marls and coal) about. ........12

14 Bluish gray limestone of fine texture, with some arewaceous material. It has very regular bedding planes and is cut by vertical joints. It contains calcareous cone-in-cone structures forming thin plates with fine striations on the surface....... 2

13. Dark and bituminous limestone............ 4

12. A dark and coaly shale ................... 2

Number 13 in the above is identical with number 13 in the previous section. Part of the concealed strata are the shales, coal and marls described as numbers 21 and 27 in White's section already referred to and are also to be correlated with numbers 1 to 7 in the section on. Indian creek (No. XII). At this latter place the first six numbers are exposed in and about a pit made in prospecting for coal.

XII. SECTION ON INDIAN CREEK IN THE SW. $1 / 4$ OF THE SE. $1 / 4$ OF SEC. 14, SCOTT TOWNSHUP, FREMONT COUNTY.

10. Dark fissile shale

FEET.

9 Limestone of dark color bituminous, weathering to brownish yellow color. When polished it is seen to consist of thin and curved, flat fragments mostly in a horizontal position. They have a thin white encrusting coat. A clastic matrix is absent but the fragments are firmly beld together by what appears to be infiltered translucent calcite. Some hard red grains are to be seen, probably partially oxidized pyrites. Some siliceous material is also present $\ldots \ldots \ldots \ldots \ldots \ldots \ldots \ldots \ldots \ldots \ldots \ldots \ldots$

8. Concealed, probably only................

7. Grayish yellow marly material containing a small Produclus (longispinus ?) joints of crinoid stems. Ammodiscus and denticles of annelids ......... 1

6. Black shale ........................... 2

5. Gray or bluish gray marly shale with a small admixture of fine siliceous sand, some mica scales and fragments of shells: Fossils: occasional small valves of Ambocalia planoconvexa, a minute ostracod, frequent and well preserved Ammodiscus, and a rhizopod like Textularia .......... 1,4

4. Dark shale .........................

3. Gray shale ....................... $1 / \frac{1}{1}$

2. Coal containing brown flattened macrospores with three radiating lines on one surface, about onefifteenth millimeter in diameter. $\cap_{n}$ the horizontal cleavage plains of this coal some straight 
thread like impressions were noted resembling very slender leaves or stems, .01 millimeter in diameter ........................ (?)

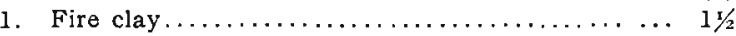

XII. SECTION OF UPPER PART OF THE EXPOSURE IN BLUFT NEAR THE NORTH. WEST CORNER OI SEC. 26, SCOTT TOWNSHIP, FREMONT COUNTY.

4. A dark oluish limestone of tine texture along some layers and along other seams almost wholly made up of very small and thin shell fragments, lying flat, barely visible under a good hand lens. Thin and wavy plates of cone-in-cone and fi'urous calcite occur in this ledge.................. 2

3. Shaly silt........................ I

2. Dark gray, in places brownish, limestone, with some fo:sils. A ground specimen is seen to consist of thin pieces of shells, 1 to 3 millimeters across, lying flat in a sparse matrix holding also a few small quartz grains...............

1. An arenaceous and calcareous rock of fine texture and of bluish color, consisting of a siliceous, well assorted silt or sand imbedded in calcareous material. It contains frequent specimens of a Cythere, also a Fenestella, other bryozoa, and fragments of brachiopod shells. .......... $21 / 2$

XIV. GENERAL SECTION OF SEVERAL EXPOSURES NEAR THE CENTER OF THE NORTH LINE OF SEC. 35, SCOTT TOWNSHIP, FREMONT COUNTY.

9. Blue limestone weathering brown with many joints of crinoid stems and broken into a discontinuous stratum of small bowlders................. (?)

8. Chocolate colored, sparingly sandy shale, marly and slightly micaceous, containing horizontal seams of small calcareous nodules of gray color. . $31 / 2$

7. Yellow marl with small calcareous nodules, about.. 5

6. Gray marl with many fossils: Ammodiscus, Lvpho. phyllum proliferum (?), Fistulipora nodulztera (fattened), Rhombopora lepidodendroides, Seplopora biserialis, Polypora submarginala (?), Feneslella (?), Choneles granulifera, Ch. vernuiliana, Spirifer cameratus, Spiriferina kentuckensis, Pugnax ula, Syntrielasma hemiplicala, Ambocalia planoconvexa (both valves), Productus semireticulalus, Murchisonia (?), Nucula (?), denticles of brown color ......................... 1

5. Soft gray limestone with some fossils. In the lower part of the ledge vermicular vertical extensions of dark material were noted. The rock contains 
clean organic fragments in an almost structureless

matrix......................... 7

4. Hard blue limestone with many crinoid stems and cut by vertical joints. A ground specimen shows occasional fusulinas and clean and also incrusted fragments of shells imbedded in a copious dark matrix mostly structureless, but also showing indistinct small granules. The organic particles seem to be indurated, as if by infiltration of silica, exposed about.................. 1 (Below this there were some 3 or 4 feet not exposed. Most of this space is apparently taken up by limestone, which has been quarried and is now covered by debris.)

3. Red shales containing fine quartzs and, some mica and some calcareous material. The later is mostly gathered into gray concretions, less than 1 millimeter in diameter. ................. 2

2. Grayish blue, finely arenaceous silt with some mica. Some seams aie hardened by the deposit of a strong intersticial cement of calcite...........6 6

1. Red shale.......................... K

The above section is not quite continuous. Numbers 1,2 and 3 are seen in the bank east of the wagon road, and the remaining numbers appear in a quarry in the slope above. About fifteen feet below its base there is seen in the ditch along the road leading west, some twenty rods distant, a limestone which is much disintegrated.

Between the road and the creek on the north line of the northwest quarter of section 31 in Green township, east of Thurman, is an old quarry now concealed. Soma blocks of a sound hard limestone were seen in the rubbish which was overgrown with underbrush.

Section XV which follows is seen south of Thurman and includes twa exposures about two-thirds of a mile apart. Numbers 1 to 4 are seen east of the wagon road in the northwest quarter of the southwest quarter of section 12 and numbers 4 to 6 appear. in the northwest quarter of section 13, the limestone in both places appearing to be the same (number 4). Near the latter place a well was mad'e west of the wagon road, and a limestone was encountered some forty feet below the exposed shale. 
$x \nabla$. SECTION OF EXPOSURES IN THE BLUFFS TWO MLES SOUTH OF THURMAN.

6. Bluish gray sandstone of fine texture, cemented by a crystalline calcareous matrix ............ $1 / 2$

5. Gray shale, not calcareous, evidently in part originally a black shale..................... 10

4. A dark gray, blotched limestone cut by straight and vertical joints into large blocks and containing numerous spheroidal calcareous lumps about onefourth inch in diameter. In section is seen to be composed of an agglomeration of indurated lumps of calcareous mud, of all sizes up to one-half inch in diameter and of varying color due to weathering. The larger of these are themselves occasionally composed of agglomerations of smaller nodules. Some show shrinkage cracks and fissur. ing. In this mass are a few shell fragments, joints of crinoid stems and quartz grains .......... 3

3. Soft bluish gray shale (partially concealed) .......2

2. Grayish blue sandstone of fine texture and indurated by a crystalline calcareous matrix, in straight layers below and ripple bedded above......... 3

1. Shale, not well exposed $\ldots \ldots \ldots \ldots \ldots \ldots \ldots$

Concealed ...........................40

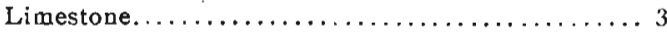

XVI. SECTION IN A QUARRY EAST OF THE CENTER OF THE WE3T LINE OF THE NW. 1/4 OF SEC. 23 , SCOT $\Gamma$ TOWNSHIP, FREMONT COUNTY.

2. Gray marl with fossils.................

1. Limestone, blue and hard bel $2 w$, softer, gray and more fossiliferous above. In a ground specimen the rock is seen to consist of a copious, compact, structureless and dark gray matrix, in which lie a few clean organic fragments and also some very unevenly distributed, oblate or round oölitic grains with thick crust. In places the exterior of this oolitic crust is replaced by iron pyrites. Fossils: Rhombopora lepidodendroides, Productus costalus, $P$. cora, $P$. nebraskensis, S:minula argentea (large), Ortiis? (large), Myalina swallowi, Avicula longa, Aliorisma subcuneata, Entolium aviculalum, Aviculopinna americana, Sphaerodoma primogenius ...................... 2

XVII. EXPOSURE IN THE ROAD NEAR THE EAST UINE OF SEC. 6, WASHINGTON TOWNSHIP, FREMONT COUNTY.

2. A decayed limestone originally dark in color and containing sand and mica scales, being largely a mixture of eacrusted shell fragments and calcareous mud............................

1. Gray shale, originally dark................ 
XVII'. GENERAL SEOTION OF THE EXPOJUR IS NEAR THE HIGH BCHOOL IN HAMBORG.

7. Gray shale, somewhat disintegrated and leached, giving no response to acid and evidently originally dark, containing disc-shaped concretions of iron pyrites about an inch in diameter and a few thin seams of arenaceous material above. When washed it yielded brown scales of rhomboid form, some fine, tubular and jointed bodies and a rhizopod resembling a textularia............ 15

6. A dark gray, arenaceous limestone with occasional scales of mica. On a polisbed surface the sand grains were seen to measure from one-eighth to one-fourth millimeter in diameter. In the main it is breccia of organic fragments with a sparse matrix, one-half of the bulk of the rock consisting of organic fragments more than one millimeter in diameter and surrounded with a crust of structureless material. There are also some imbedded minute tubules about one millimeter in diameter. Occasionally there are imbedded lumps of lighter color. Fossils: Bryozoa, fish teeth (?), chitonous denticles of small size, and poorly preserved specimens of Ammodiscus. . ................ $3 / 4$

5. Gray, calcareous and arenaceous shale......... $1 / 4$

4. Bluish gray rock consistiıg of fine sand and organic calcareous fragments slightly encrusted....... $1 / 3$

3. Shale ..............................

2. Fine-grained, blue sandstone with a crystalline calcareous cement and showing ripple marks.... 2

1. Shale, micaceous, arenaceous and slightly cal.careous, exposed.....................

These exposure are somewhat scattered, some being seen on the street north and some on the street south of the high school grounds. A ledge of limestone was also seen below the bluff to the north near some wells which furnish part of the city water. This probably corresponds with number 6 in the above section.

\section{SECTIONS IN THE UPLANDS EAST OF HAMBURG.}

XIX. SECTION IN THE CREEKS IN 8 . $1 / 4$ OF SEC. IB AND ADJOINING QUARTERS OF SECS. 18 AND 24. TWO MILES EAST OF HAMBURG.

$$
\text { FEET, IN- }
$$

26. Gray shale, not calcareous, composed of fine silt and containing very little arenaceous material ......................... 7

25. Dark gray marl, composed largely of minute 
organic fragments. Fossils: Rhomboporalc $p$ CH YS. idodendroides, Ambocaiia planoconvexa, Aminodiscus (?) and minute conical fluted fish teath, rhombcidal, brown, small but thick enameled fish scales (measuring one-third millimeter across), spines and flakes of brachiopod valves ..........................

24. Dark, almost black, arenaceous limestone. In a polished specimen it is seen to consist of a matrix of fine calcareous material mixed with fine quartz sand and a few mica scales. In this are embedded numerous worn fragments of shells and other animal remains, and also occasional lumps of greenish clay and calcareous material. All of the fragments have a more or less calcareous, accretionary crust. In some cases the fragment is small and the crust thick so as to make true oölitic sperules with organic centers. Joints of crinoid stems occur. Some of the calcareous lumps are a half inch in diameter and have corcentric layers surrouoding a dark structureless center showing healed shrinkage cracks. The shell fragments range in size from 2 to 10 millimeters. Fossils observed: Derbyacrassa and Rhombopora lepidodendioides ...................

23. Fine-grained, bluish and micaceous sandstone weathering to yellow and brown. The sand is cemented by a crystalline calcareous matrix The sand is well assorted, consisting mostlyof grains ranging from one-fourth to one-sixteenth millimeter in diameter and with angular contours. A few grains have a green color.

22. Micaceous and atenaceous, grayish blue silt or shale of finer texture than the previous number, and lacking the calcareous cement, but otherwise of similar composition ............. 3

21. Seam of sandstone like number $23 \ldots \ldots \ldots \ldots$

20. Blue shale like number $22 \ldots \ldots \ldots \ldots \ldots \ldots \ldots 2$

19. Ripple bedded sandstone like number $22 . \ldots \ldots$

18. Concealed ...................... ?

17. Gray shale ...................... 4

15. Dark, shaly and soft limestone more indurated above and softer below, filled with fossils and containing bits of black woody tissue. In a polished specimen it is seen to consist of an unassorted mixture of clean shell fragments of all sizes and impalpable calcareous mud. 
There is also a very small admixture of minute quartz particles and some granules of pyrites of iron. Fossils: Derbya crassa, Plenrolomaria perhumerosa? Spiriter cameratus, Productus punclatus, $P$. semireliculaius, $P$. longispinus, $P$. costatus, Choneles granulifera, Ambocclia planoconvexa, Macrodon lenuislrlatis(?) Edmondia nebraskensis (?) Mualina, Nucula (?) Schizodus (?) Rhombopora lepidodendroides, joints of crinoid stems, chitinous denticles of annelids and calcareous tubules.............. 3

15. A pure coal with black streak and with thin horizontal seams of charred wcody fibre. When ground it yields frequent macrospores, flattened, brown, two-thirds millimeter in diameter with three radiating ribs on one face. At the outcrop the thickness is only ........ 1

14. Yellowish, evidently somewhat weathered fire clay, seen .....................

13. Concealed .......................?

12. Shale, highly weathered and including above some indistinct, highly disintegrated layers of gray, yellow limestone or marly beds ......22

11. Dark limestone, easily broken and containing many fossils. When ground and polished it is seen to be an organic breccia with a somewhat copious and dark argillaceous matrix. The shell fragments are clean and somewhat rounded by attrition. It contains horizontally placed thin seams of brownish and vertically fibrous calcite. Fossils: Joints of crinoid stems, Rhombopora lepidodendroides, other bryozoa, Produclus nebraskensis, Bellerophon montfortianus, Schizodus (apparently several species), dentalium (?) and Ammodiscus ............

10. Dark shale......................... 3

9. Dark, almost black limestone. In a polished sample it is seen to be an unassorted shell breccia, in which the matrix is very sparse. The fragments are clean, and mostly unworn. Mingled with these are some round lumps of compact, apparently clastic, calcareous material. Throughout the mass there are small tubules from .05 to 2 millimeters in diameter, curved and sometimes placed side by side in rows, or other groups. Granules of pyrites occur. When crushed and washed the rock yields some small lamellibranchs........... 
8. Dark biuish shale, weathering to yellow ...... 3

7. Concealed, probably shale, about,......... 3

6. Grayish, light c slored limestone. On a polished surface it is seen to consist of a copious, almost structureless and compact matrix which is fissured by many minute joints healed with calcite as if incipiently brecciated. In this matrix are held frequent fusulinas and a few scattered shell fragments of about the same size. Fossils: Joints of crinoid stems, Fusulina cylindrica, Rhombopora lepidodendroides, Produclus semireliculalus............... 2

5. Concealed....................... ?

4. Limestone, yellowish gray, very much decayed above. A sound hand specimen exhibited a texture and structure like that in number 6 , except that it contained some lumps showing a lighter color than the rest of the mass. Fossils: Seblopora biserialis, Fisiulipora nodulifera, Fusulina cylindrica llong and slenderl, jaw plate of Archæocidaris and joints of crinoid stems...................... 4

3. Shale, dark bluish gray below and yellow above. a sample from the lower part contained a few mica scales and was also calcareous ....... 8

2. Concealed ........................ 4

1. Greenish, dark gray limestone with many fusulinas and consisting of a copious matrix of fine texture containing unassorted organic fragments. Fossils; crinoid stems, some bryozoa, small gaste-opods, Fusulina cylindrica (long and slender, sometimes twisted, forms) . I

Numbers 1 to 4 appear in a creek a little south of the center of section 13, close to the wagon bridge. Numbers 6 to 12 are seen about a quarter of a mile farther up in the same creek, at successive points. Numbers 14 to 17 outcrop close to the west section line in the creek in the soulbwest quarter of the southwest quarter of section 18 (Tp. $67 \mathrm{~N}$., R. XLI W.), and numbers 18 to 25 appear in a tributary from the scuth in section 24 (Tp. 67 N., R. XLII W.). Though separated by a distance of about a half mile it is quite evident that they occur in the succession indicated. 
XX. OUTOROP UNDER THE BRIDGE ONE-QUARTER OF A MILE WEST OF THE SOUTHEAST CORNER OF SECTION 18. MADISON TOWNSHIP, IREMONT COUNTY.

The following outcrop is probably included in the highest number of the previous section.

3. Dark compact limestone with clean shell fragments, only loose blocks seen.................. ?

2. Concealed .......................... ?

1. Blue shale, free from calcareous material and containing no fossils ................... 5

XXI. SECTIONS IN TWO WELLS IN THE SW. 3/4 ON SEC. 1. TP. HT N., R. XLII W. Bridges' Well.

3. Drift and probably shale..................... 39

2. Disintegrated limestone with Productus and other fossils, about ...................... I

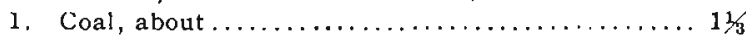

McMillan's Well.

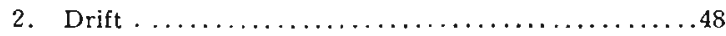

1. Blue sandstone of fiae texture with some shale... 8 ?

Bridge's well has its curb about fifty feet below McMillan's well and the coal which was explored there no doubt lies some distance under an arenaceous rock wlich was penetrated near the bottom of Bridges' well. Both of these wells are near the south line of the section, and the latter is farthest to the east. Another of Bridges' wells is on higher ground about 80 fuet alrove his Jower well. The section of this one is as below:

XXII. SEOTION OF BRIDGES' UPPER WELL, IN THE SW. 4 OE SEC. 1, TP. GT N, R. XLII W.

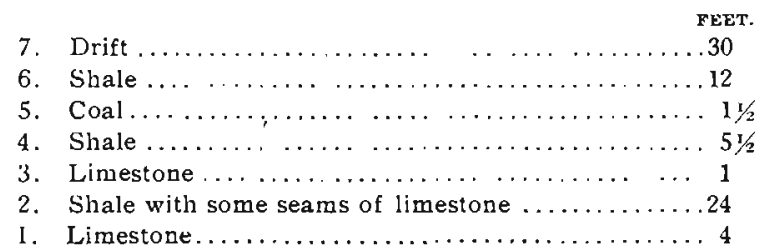

The elevation of the curb of this well is about 1,030 above sea level, or about 130 feet above the bottoms to the west. 
XXIJ. SECTION ON MILL CREEK NTAR THE CENTER OF THE SW. 1/1 OF SEC. 33, RIVERTON TOWNSHIP, FREMONT CUUNTY.

9. Shale, yellow and weathered............... 10

8. Three or four ledges of solid and strong limestone separated by seams of greenish shale. One of the ledges from the lower part of the number is a gray rock and contains copious clsan fragments of criboid stems, brachiopod shells and plates and spines of Enctdaris hallanus(?). One of the ledges above is unique in structure. It is hard and white, and is composen of thin and rounded fragments of shells, all horizontally placed. They measure from 1 to 2 millimeters in width, and lie embedded in a inatrix of clear crystalline calcite. The fragments themselves appear as if consisting of the same material, their outlines merely being marked by thin white lines. Occasional specks of iron pyrites appear. 'On one surface of this ledge were noted: Myalina swallowi (?) Aviculopeclen whileyi and Brllerophon marconanus........... 3

7. Yellow, slightly ocherous marl, or decayed limestone ......................... $21 / 2$

6. Blue calcareous shale with yellow blotches and small compact concretions above. Organic fragments and some sand gra:ns occur.............. 4

5. Concealed, probab.y limestone, about......... 2

4. A thin seam of soft sandstone composed of fine quartz grains, well assoited, with some mica.... $1 / 6$

3. Friable and somewhat shaly silt with some seams very micaceous $\ldots \ldots \ldots \ldots \ldots \ldots \ldots \ldots \ldots \ldots \ldots, 4 / 2$

2. A fine-grained and micaceous samdstone firmly cemented by crystalline calette, varying in color from bluish gray to brown, and containing occasional small joints of crinoid stems........... 2

1. Bluish gray shale interbedded with reddish arenaceous seams, somewhat micaceous. Large and ramifying calcareous concretions are lodged in vertical or inclined joints which appear on the exposed surface ...................... 8

SCATTERED EXPOSURES.

The narrowing of the Silver creek bottoms south and west of Malvern indicates the presence of bed rock. It rises above the level of the battom in some places along the bluffs in section 5 , Tp. 71 N., R. XL W., and limestone has been quarried at a few points, including the place where the following section was observed. 
XXIV, SEOTION NEAR THE BANKS OT STLVER ORETK ONE.THLRD MILE WEST OF THE OSN TER OF SECIION 5, WHITE OLOUD TO NNSHIP, MILLS COUNTY.

FHET

6. Marly shale.......................

5. Grayish, cream-colored, fusulina limestone in three or four strong ledges. The fusulinas with some large sized fragments of shells, lie imbedded in a matrix consisting of a compact mass of minute fragments of organic material. About 14 inches below the top of this number it contains a layer of black and in places gray chert, with the same texture, including the fusulinas. Fossils: Fusu. lina cylindrica, Syringopora, sp., a small gasteropod and a.small cyathophylloid.coral. (This number is largely removed by cavern erosion. The walls of the old caverns are in places covered by a stalactitic crust, and the cavities are filled with bluish cavern clay) $\ldots \ldots \ldots \ldots \ldots \ldots \ldots \ldots 6$

4. Grayish blue, compact limestone, having some fragments with oölitic crust $\ldots \ldots \ldots \ldots \ldots \ldots \ldots, 2 / 3$

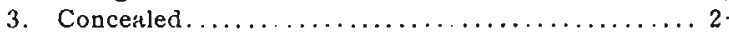

2. A yellow limestone, breaking into thin, small, irregular slabs from one to three inches in thickness. It is composed of a compact matrix of calcareous mud, in which are imbedded clean fragments of crinoid stems, bits of shells and a few bryozoa and Fusulina cylindrica.......... 2

1. Limestone, quarried, but now cuncealed, about... 3

In the bed of Spring Valley creek a short distance to the south of the center of the north line of section 36 Rawles township, Mills county, some limestone was once quarried. The section is as given below. The quarry is now covered. The upper ledge is said to have been scored, the striae bearing in a northeastsouthwest direction. Some rocks beautifully scored from this edge may yet be seen in the cellar of Mr. John W. Glynn's house.

KXV. SECTION IN SPRING FALLEY CREEK, IN SES. 35, RAWLES TOWNSHIP. MILLS COUNTY.

FEET.

3. A dark bluish compact limestone containing some clean and some encrusted organic fragments of varying sizes, among which some small spires of gasteropods and some joints of crinoid stems were noted. Loose pieces of fusulina b saring rock were observed........................ $11 \%$

2. Shale, dark, not well exposed.............. 2 
1. Compact, yellowish white limestone with irregularly FEET. tubular and fissure like ramifying cavities, averaging one millimeter in diameter and filled with clear calcite. The rock consists of minute organic particles among which are numerous curving tubules, less than one-tenth millimeter in diameter. Along some irregular streaks the rock is quite opaque and white, but otherwise like the rest in structure. These streaks are trenchantly marked off from the rest on a ground surface......... 11/2

XXVI. SECTION IN AN OLD QUARRY ON PLUM CREEK IN TEE SW $1 / 4$ OF SEC. 17 , GREEN TOWNSHIP, FREMONT COUNTY.

2. Grayish ye!low marl containing fragments of Septopora biserialis, spines of various kinds, joints of crinoids and small oval shells of some ostracods.. 3

1. Yellowish white limestone consisting of a matrix of minute organic fragments with cölite incrustations. In this lie imbedded larger oülitic sperules with centers of dark organic fragments surrounded by thick crusts of concentric layers. The largest measure 2 millimeters in diameter. The rock is cut by some minute fissures healed by crystalline calcite................... 2 ?

The quarry has been abandoned and is now almost wholly covered by wash from the creek. The above section lies about fifteen feet above the water in the creek.

Correlations.-On comparing the sections just described it will be seen that V, VI, VII, VIII, IX and $X$ are composed of the same limestone with the same shales overlying in V, VI and X. Sections I, II, III and IV probably underlie these, the latter at no great distance below. Numbers 4, 5 and 6 in XIV are perhaps identical with the lower main limestone in V and VI. Numver 9 in XII and 16 in XI are identical. Number 8 in XXIV is probably the same as 4, 5 and 6 in XIV. Number 15 in XIX and number 2 in XII are apparently equivalents, and as 4 and 6 in $\mathrm{XrX}$ resemble 1-4 in $\mathrm{X}$, the exposures in the region around Hamburg, which are represented by 12-26 in XIX, probably, overlie all of the rocks exposed in the country north of Thurman. The limestone near Malvern, seen in section XXV, is identical with the main limestone east of Wabonsie lake, 3-5 in V. A general section for the two counties would hence be about as follows: 


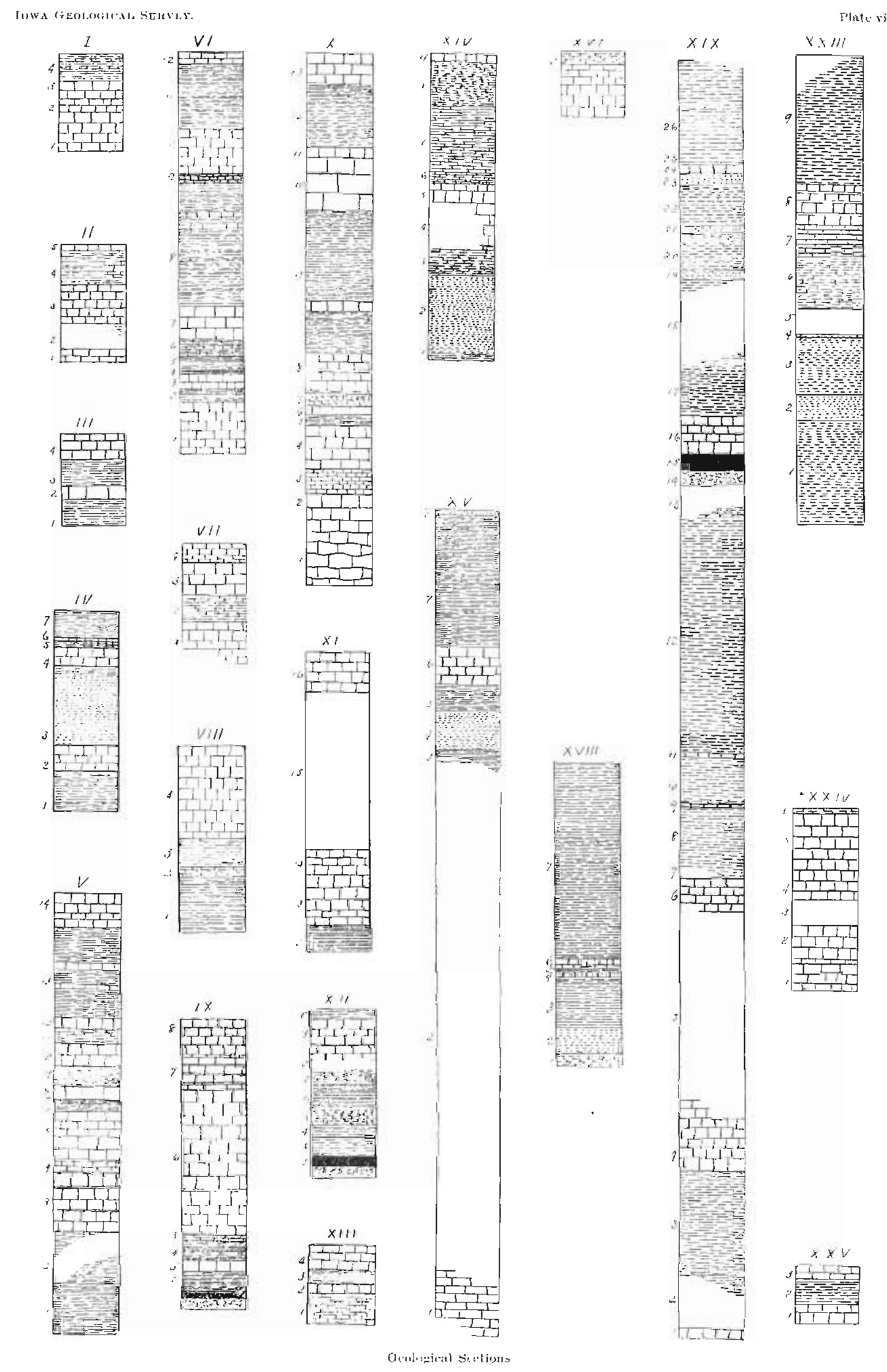


GENERAL SECTION.

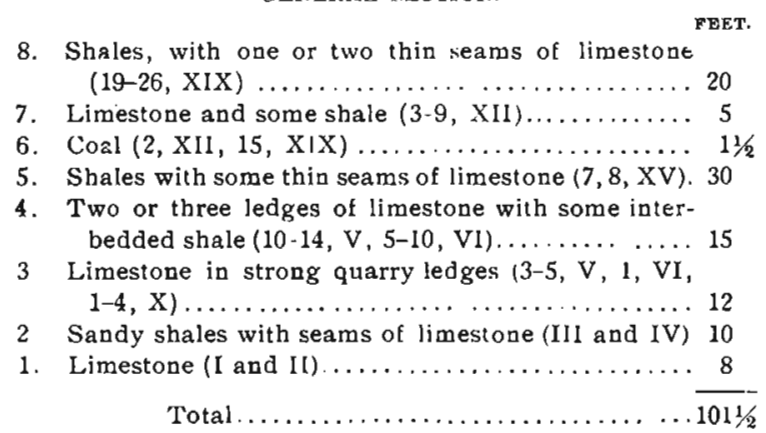

Number 3 in this general section is the equivalent of the principal quarry lediges at Nacedonia in Pottawattamie county and numbers 5, 6, 7 and 8 are the equivalents of the upper part of the section in the bluffs below Nebraska City, Nebraska. The coal, number 6, is probably not the Nodaway. At least it differs from this in always containing a notable number of macrospores which the Nodaway coal does not. The limestone in V, VI, VII and VIII is believed to be the equivalent of numbers $1-3$ in Meek's Rock Bluff sections in Nebraska.* The entire section, including all the Coal Measure rocks exposed in the two counties, belongs to the Missourian stage, aud presumably overlies the Nodaway beds of the same stage.

Geographical Conditions: Faun and Flora.-The geographical conditions under which the Missourian deposits were laid down are to be made out from the rhysical character of the beds themselves as well as from the plart and animal remains which they contain. These indicate off-shore conditions, snch as prevail on a continental shelf, alternating with more shallow and less open waters. A considerable part of the shales contain fine, arenaceous material such as is common in the deposits out on a continental shelf. The limestones indicate a still more open sea. 'The coal seams and the black and clayey shales, on the other hand, were laid down in lagoons ner the shore. Plant remains are rather scarce even in connection with the coal seams, which themselves have a small development. The presence of Fusul-

\footnotetext{
- Report on thi. Puleontology of Eustarn Nebraska, F. B. Mork, p. !n.
} 
ina, of Ammodiscus, of other foraminifera and no less the abundance of echinoderms and especially crinoid remains, testifies to the presence of deeper waters at intervals. Below is given a classified list of the fossils noted.

PLANTS.

Ferns, wood and macrospores.

ANIMALS.

PROTOZA.

Ammodiscus . *

Fusulina cylindrica.

Textularia?.

Rbizopod (plates).

Rbizopod (tubes).

Sponge (undel).

COELENTERATES.

Axaphyllum mude.

Campophyllum torquium.

Cyathophyllum (small).

Lophophyllum proliferum.

ECHINODERMS.

Archaocidaris aculeala. edgarensis.

Archæocidaris (spines.)

Archæocidaris (plates).

Archæocidaris (jaw plate).

Eocidaris halliana.

Erisocrinus typus.

Eupachycrinus verrucosus.

Scaphiocrinus (plates).

Scaphiocrinus hemispherica.

Zeacrinus (?).

Crinoids (stems).

Crinoids (plates).

BRACHIOPODS.

Ambocalia planoconvexa.

Chonetes granulitera. vernuiliana.
Fistuliopra nodulifera. Polypora submarginala. Rhombopora lepirodendroides.

Seplopora biseralis.

Syringopora.

Bryozoa (undet).

ANNELIDS

Annelid denticles.

GASTEROPODS.

Bellerobhon carbonaria.

marcouanus.

montfortanus.

Bellerophon (undet).

Dentaliun.

Euomphalus rugosus.

Murchisonia.

Pieurolomaria perhumerosa.

Pleurotomaria (undet).

Sphaerodoma primogenius.

Gasteropods (undet).

LAMELLIBRANCHS.

Allórisma subcunealum.

Allorisma (undet).

Avicula longa.

Aviculopeclen whileyi.

Aviculopecten (undet).

Aviculopinna americana.

Chenomya leavenworlhensis. minnehaha.

Edmondia nebraskensis.

* Foraminifera are present in the entire section of these two counties, more or less frequenty, - excepting the sandstones and the course -ilts. They may be found by wauhug the marla, clays, and crushed limestone. Spe'vimens have been submitted to Dr. E. Schellwein of Künigsberg, Germany, who has identiled two species of Ammodiscus belonging to the subgenus Pammophis, and an Endothyra, probably identical with Lndinyra parva Moll. Dr. Schell wein Teports ' hat one of the species of Psammophis resembles $P$. inversus, wut tho shells have a more irregular structure. In the quarry northwest of Bartiett the uoper part of oue of the lediges of limestone con whts of a felt of the Irregularly carving tabular shells of this species, the interstiogs having been flled with a transparent hard matrix of ca cite. This layer varieg from three to flre inches in thlekness and runs the whole length of the quarry. It was also noted in the same ledge about four miles farther south. 
Chonetes (undetermined).

Derbya crassa. robusia.

Dielasma bovidens.

Orbiculoidea convexa.

Orthis (undet).

Produclus cora.

costatus.

tongispinus.

nebraskensis.

perlenuis.

prattenianus.

punctalus.

semireliculatus.

Productus, (undet).

Pugnax uta.

Seminula argentea.

Spirifer cameralus.

Spiriferina cristala.

kentuckiensis.

Syntrielasma hemiplicala.

Brachiopods (undet).

BRYOZOA .

Fenestella
Edmondia (undet).

Euloluun aviculalush.

Macrodon tenuistrialus (?).

Modiola subelliplica.

Myalina recurvirostris. subquadrala. swallowi.

Myalina (undet).

Nucuta beyrichia (?).

Nucula (undet).

Pinna peracula.

Pseudomonotis hazmi.

Schizodus wneeleri ( $(y)$.

Schizodus (undet).

Solenomya (undet).

Solenopsis sotenoides.

Lamellibranchs (small).

OSTRACODS.

Cytbere (undet).

Ostracods (undet).

Philipsia (undet).

FISHES.

Fish scales.

Fish teeth (conical).

THE CRETACEOUS.

After the Coal Measures had been laid down the bottom of the sea was elevated and became land. This condition apparently prevailed during the greater part of the Triassic and Jurassic ages, for no deposits of this time occur here. The lands formed from the Coal Measure sediments were then subjected to erosion and how much of the original formation was carried away caunot now be told, but a thickness of some hundreds of feet may very well have been removed. The conditions were again reversed at some time during the Cretaceous age and the region was subwerged anew and covered by sediments of a new sea. These later deposits are quite different in appearance from the older and resemble.in this country the Dakota formation of the Western Plains.

During the Tertiary age, after the sea for the last time disappeared, the Cretaceous deposits were in their turn carried away 
and all that now remain of them are a few remnants of the lowest. part of the formation.

There is no doubt that small patches of Cretaceous deposits. lie under the drift in several places on the uplands, where they cannot now be seen. Sand and soft "sand-rock" have beer found under the bowlder clay a mile east of Emerson. Another well in the west bluffs of the Nishnabotna west of Henderson penetrated some gravel which may have: been of the same age. On the eroded surface of the limestone in the quarry at Henton there are seen some disintegrated lumps of a brown sandstone which resembles the Cretaceous in appearance. It contains almost exclusively well rounded pebbles of quartz and chert. Blocks of the same conglomerate, always highly ferruginous, occur associated with small exposures of Cral Measure rocks two miles farther south and have again been noted on top of these older rocks east of Wabonsie lake in section 23, Scott township;. Fremont county. 'The clay which fills the caverns in the limestone south of Malvern is probably also of the same age, and the same may be said of a highly disintegrated, ferruginous and soft clayey rock resting: on the eroded surface of the Coal Measure limestone southeast of the center of section 13, Tp. 67 N., R. XLII W.

While the age of the small outcrops enumerated above inust be regarded as uncertain, the Dakcta sandstone can be positively identified in two exposures in Mills county. One of these is in the low slope of the east bluffs of the Nishnabotna a little south of the center of the northeast quarter of section 22 , two miles south of Henderson, and the other is half a mile distant, northeast of the southwest cormer of section 14. Sandstone was quarried for many years at the former place, but the quarry is now partly filled. The face of the quarry appears to have been about ten feet high. The rock is a gray sandstone in heavy ledges, in places yellow or even brown. It brealis with equal readiness in all directions. Where the rock is hardest, the sand grains are held together by an opaque, white, thin layer of siliceous cement which apparently is a product of interstitial leaching and redeposition. The solvent effect of underground waters are seen 
also in the absence of the ferruginous cementing material which is common in the Dakota sandstone elsewhere, and which makes the sandstone in section 14 almost black. In the quarry in section 22 the yellow or red oxides of iron color the rock in places where perculating water has not had free passage, as along shaly seams and in concretions. At the base of the quarries the sandstone rests on gray clay, or is interbedded with this, and on the faces of some ledges there are marks which show how the two kinds of sediments, while yet in a plastio slate, have been worked into each other and broken into lumps which have slid into new positions, evidently under pressure of superincumbent sediments.

The sediments are of the littoral kind: mud, sand and gravel alternating. It is the first deposit of the advancing sea. The gravel is well worn, and consists largely of the most resistant inaterial of the underlying. Coal Measure rocks. No limestone fragments were seen, but in one blork were some angular cavities which might have contained chips of such rock, afterward removed by solution. A study of several lots of pebbles of various sizes show that the larger ones are mostly made up of chert from the: Coal Measures and this often contains silicified fragments of fossils. Most of the finer material is common quartz, as may be seen in the following table, which is based upon observations of several hundred pebbles and grains of the conglomerates and sandstonts. Evidently the larger fragments are nearly all derived from the local rooks, the more resistant material of the Missourian.

TABLE SHOWING AVERAGE FREQUENCY OF DIFFERENT MATERIALS AMONG FRAGMENTS OF BUCCESSIVE SIZES IN THE CRETACEOUS ROCKS NEAR BENDERSON, IOWA.

\begin{tabular}{|c|c|c|c|c|}
\hline Average diameter of fragmenls in millimetrs. & $8-4$ & $4-2$ & $\therefore-1$ & $1-1 / 2$ \\
\hline MATERIALS. & $\begin{array}{c}\text { PER } \\
\text { CENT }\end{array}$ & $\begin{array}{c}\text { PER } \\
\text { CENT }\end{array}$ & $\begin{array}{c}\text { PPR } \\
\text { CENT. }\end{array}$ & $\begin{array}{c}\text { PER } \\
\text { CENT. }\end{array}$ \\
\hline 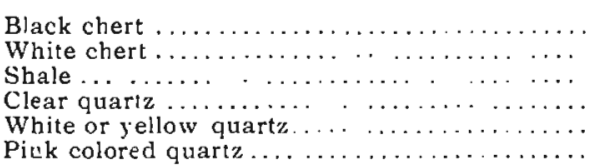 & $\begin{array}{r}37 \\
27 \\
3 \\
3 \\
22 \\
8\end{array}$ & $\begin{array}{r}7 \\
27 \\
2 \\
25 \\
29 \\
10\end{array}$ & $\begin{array}{r}5 \\
5 \\
0 \\
57 \\
23 \\
10\end{array}$ & $\begin{array}{r}1 \\
1 \\
0 \\
82 \\
14 \\
2\end{array}$ \\
\hline 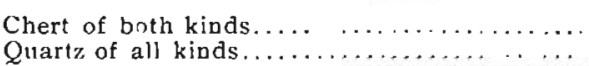 & $\begin{array}{l}64 \\
33\end{array}$ & $\begin{array}{l}34 \\
64\end{array}$ & $\begin{array}{l}10 \\
90\end{array}$ & $\begin{array}{r}2 \\
98\end{array}$ \\
\hline
\end{tabular}


The concretions already referred to are remarkably like those occurring in the Dakota sandstone of the West. They are more numerous in some of the ledges than in others. On one block no less than seventeen were counted on a surface of one square foot. They are usually spherical in shape, but in a lot of fifty, six were double and dumb-bell shaped. In these one of the pair is always slightly smaller than the other. The spheres range in size from five to fifty millimeters in diameter. In a lot of fifty-five the different sizes were represented as follows:

\begin{tabular}{r|c|c|c|c|c|c|c|c|c|c}
\hline Sizes in millimelers. & 5 & $6-10$ & $11-15$ & $16-20$ & $21-25$ & $26-30$ & $31-35$ & 3640 & $41-45$ & 50 \\
\hline $\begin{array}{r}\text { Number of cunc.re- } \\
\text { tions of different } \\
\text { sizes.............. }\end{array}$ & 1 & 4 & 11 & 12 & 12 & 5 & 5 & 2 & 1 & 1 \\
\hline
\end{tabular}

The interior of most of them consists of sand grains of the same kind as in the rock outside, with a loose packing of yellow ochre or clay, probably a residuum after pyrites of iron. In other cases the center consists of a lump of clay.

In section 14, northeast from the old quarry, the rook is brown, and in places almost black, sandstone with a conglomeritic layer on top. It is cut at one point by old worn joints into long and narrow blocks. A thickness of only a few feet is exposed and the ledge runs for some rods at the foot of the slope.

No fossils oscur at either of the two outcrops. Their age has been sufficiently discussed in the reports on the adjacent counties. They evidently belong to the same epoch as the Dakota sandstone of the Plains.

Erosion Interval.-After the Cretaceous sea had disappeared the land was again subjected to erosion during the Tertiary age and reduced to the present level of the bed rock. A considerable thickness of the latest sediments may thus have been washed away and also a part of the Coal Measures when this period was brought to a close by the coming of the ice age. 
Pleistocene.

Ante-Glacial Silt (?).-During the glacial period the land in this region was covered by a great continental glacier, which formed a heavy deposit of bowlder clay. Under this clay lies in some places a silt, which frequently is highly calcareous and in other respects also seems to be closely related to the drift. Sand and gravel.is occasionally associated with this silt and interbedded with it. In one place a tunnel-like hollow in the silt is seen to be filled with sand. This is in the Misouri river bluffs a little south of the center of section 32, Oak township, Mills county. In other places it has been much affected by water, which has percolated through porous strata and deposited white calcerous flour and sometimes a dark material like wad. An instance of this appears in the base of the bluffs a little east of the center of the north line of section 5, Plattsville township, Mills county. It is here regularly laminated and grades: above into a loess-like material. Below it is variable in color, changing from gray to green, purple, yellow and almost white. At another place in Mills county it appears to have been broken up or kneaded into irregular lumps, which are separated by seams of other clayey material. This was noted in a fresh excavation seen north of Henton station during the summer of 1900. The section was as follows:

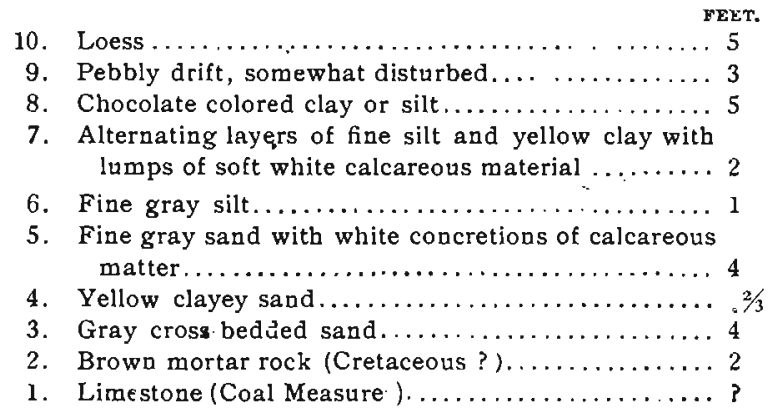

The dividing plane between the silt and the bowlder clay at this place was irregular and not unlike an unconformity, but as the bowlder clay was evidently disturbed by settling, the two unay very well have been conformable originally. 
The pebbles which occur in this silt and sand are mostly chert and of the kind found in the sand of the present Missouri river and it is possible that it may be a river silt of preglacial age, but judging from general appearances and from its association with the glacial drift the present writer is inclined to the view that it was made contemporaneous! $\%$ witl the glacial drift, and probably at a time when the great river and the ice were contesting the ground. A somewhat different view is taken by Prof. J. E. Todd, who has made many observations on the same silt in this region. As it resembles the ante-(immediately preceding) glacial silt noted in other parts of the state, that designation is here retained.

The Boulder Clay.-There is harily any evidence as to whether the bowlder clay of these two counties belongs to one and the same ice invasion or to two or more. Exposures are few and in digging wells the bowlder clay is usually found to be quite continuous below the loess down to the bed rock. It contains no well defined sheet of sand or other demarkations. The lower part is usually dark and contains pieces of wood and fragments of coal, like the Albertan drift farther east. The upper part is more frequently yellow and weathered like the Kansan drift. Probubly both are present, although there is no way of definitely distinguishing the one from the other. Occasionally wells have gone into yellow and almost red, oxidized drift under the dark bowlder clay, but such changes may very well have been caused by local underground leaching and oxidation.

Much of the bowlder clay has been removed by post-rlacial erosion, as can be made out from the topography of the region, and the erosion has been most effective to the west where the thickness of the bowlder clay is least, averaging perhaps only about seventy-five feet. On going away from the Missouri the thickness increases and along the east side of the two counties it is as much as 200 feet in some places and averages at least 150 feet. Most of what is known about the bowlder clay in these counties has been learned in making deep wells. One such well was recently made at Tabor by Mr. D. L. Horne of Gretna, Nebraska, who has kindly furnished a record of the material ex- 
plored. This record, which may be regarded as typical, is as follows :

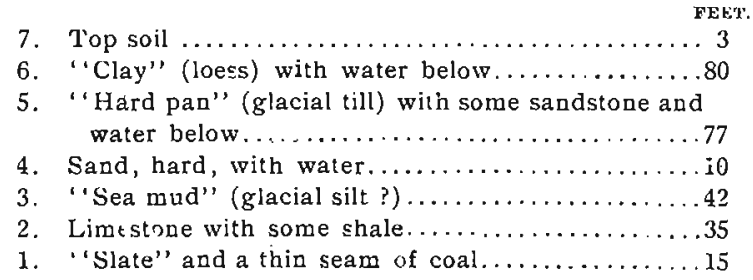

The erratics of the drift are of the same character as in Pottawattamie county. Large bowlders are scarce, very few more than three feet in diameter having been noted. It is not without interest to note that a piece of copper, weighing a half ounce, was found in heavy quicksand 220 feet below the surface in a well made near the center of the northeast quarter of section 18 in Rawles township, Mills county. It illustrates the wide distribution of the rocks of the Superior region over the area of the drift.

The Gumbo.- In some places the bowlder clay is overlain by a reddish yellow, clayey deposit, more or less like the loess but less porous, owing to the presence of a fine, ochreous, intersticial material. This gumbo is always thoroughly leached, never calcareous, but in some places it contains scattered pebbles. The latter phase was observed near some of the remnants of flat uplands southeast of Minneola. The transition from this gumbo to the loess above is usually well marked, as may be seen at Emerson north of Riverton, and also around Malvern. The gumbo is probably an old loess, in places mingled with sediments in former ponds or lakes on the old drift plain. At other points it is probably compased of ald alluvial deposits.

THE LOESS.

The loess cover's the uplands almost everywhere and is also to be seen on all alluvial terraces. Only where the upland slopes are quite steep does the bowlder clay come to the surface. The average thickness of the loess is estimated at about sixty feet, but in the bluff of the Missouri river and for two miles east, it 
frequently attains a thickness of a hundred feet and is occasionally 150 feet. This marked thiclsening causes an ill defined ridge along the west border of the uplands in some places but it has been so greatly affected by erosion that it now exists mereiy as a skeleton of divides among labyrinths of gullies and ravines. On alluvial terraces the deposit is far less heavy, ranging from five feet on the lower terraces to thirty or forty feet on the higher ones near the bluffs of the Missouri.

In its structure the loess is of the common type, a highly porous, dust like deposit, grayish yellow toward the Missouri river and more yellowish farther east, fracturing most easily vertically and horizontally and when undermined always brealsing so as to expose vertical walls. Ocasionally it contains ocherous seams on the uplands and these have a tendency to conform somewhat in their course to the surface of the land. Calcareous concretions are common in many localities but they are mostly of sinall size and irregular shape in these counties.

A singular structure, which the writer has previously observed in Pottawattamie county occurs here also. It consists of fluted horizontal shearing planes. Such shearing planes were noted in the lower part of the loess in the wagon road leading up the bluff north of the East Nishnobotna, north of Riverton, and on the side of the wagon road running north and south near the center of the east line of section 31, Tp. 73 N., R. XLII W. Their direction at the latter place is $\mathrm{N} .25^{\circ} \mathrm{W}$. The most extensive development noted is at the foot of the south bluff of Keg creek in Glenwood. In Hall's brick yard flutings are seen in the clay pit and appear again to the northeast in several places. Their direction varies here at different points, N. $68^{\circ} \mathrm{W}$., E-W, W. $7^{\circ}$ $\mathrm{S}$, having been noted.

An instance of a pebble-bearing loess occurs in the bluffs just north of Henton. A vertical wall about twenty feet high is exposed. The upper one-third of this loess is quite typical in its aspect and carries the common loess pulmonates. This changes below into a sandy deposit mingled with loess, pebbles and some broken shells of land snails. The pebbles are confined to an irregular seam or streak. Below this is again a loess-like, gray 


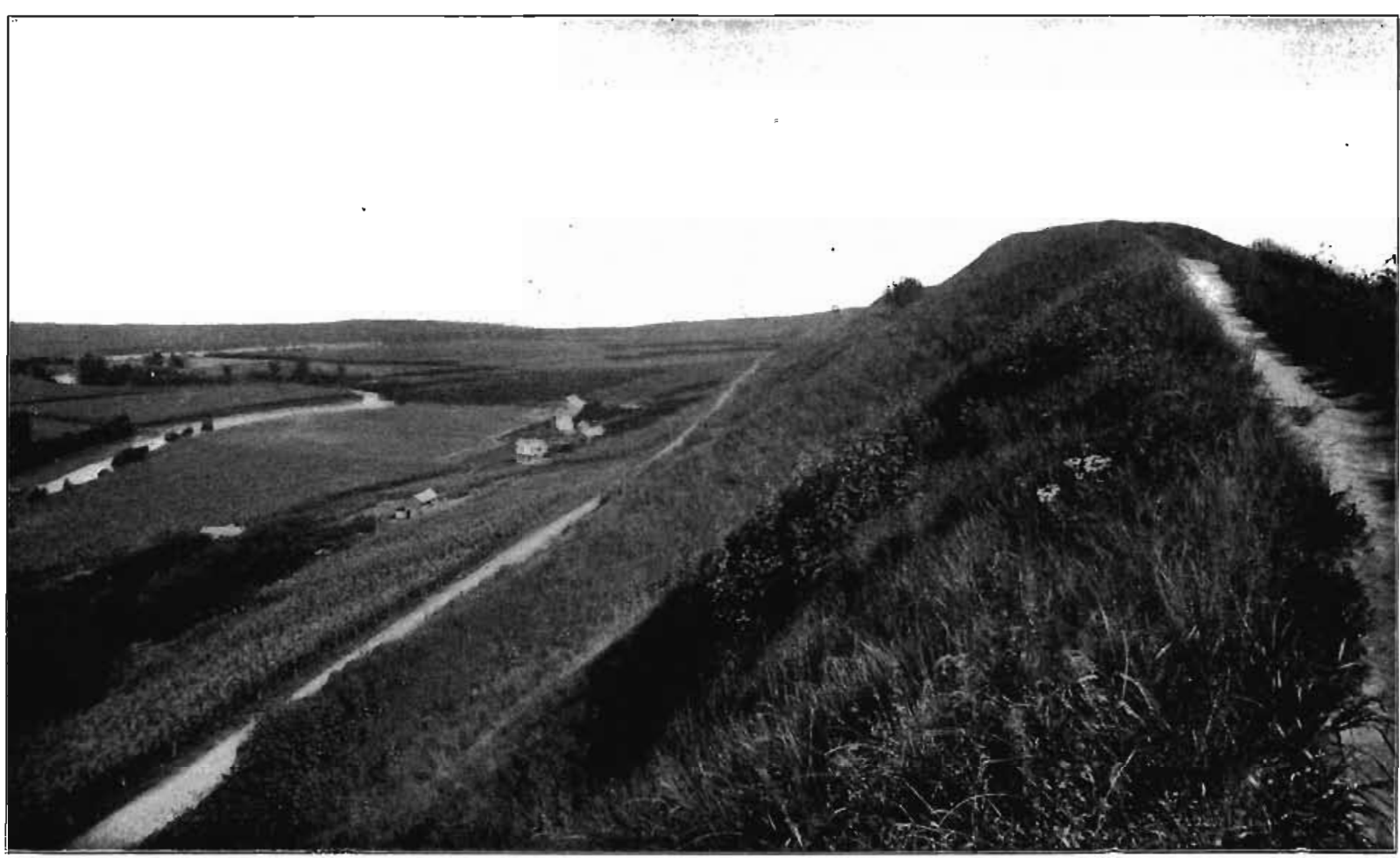

Loess rddge and alluval plain of the Missouri river west of Hamburg Photo by H. H. Stich. 
lane page taring

p. 169 (VB)

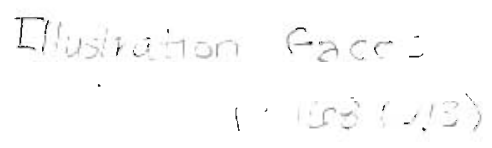

. 
material separated by wavy, joint-like lines into laminæ about one-half inch thick. Below this the talus conceals the section, which however appears to contain some bowlder clay and gravel. An examination of the pebbles showed that many of thein were scored and that in other respects they resembled unworn and fresh pebbles of the glacial drift of the region. The limestone pebbles are mostly from Coal Measure strata. The following table shows the proportions in percentages of the different kinds of rocks which are represented in the different sizes of about 250 pebbles examined.*

\begin{tabular}{|c|c|c|c|}
\hline KIND OF ROCK. & $\begin{array}{l}\text { ONE INCH IN DI- } \\
\text { AMETER; FRE- } \\
\text { QUENCY IN } \\
\text { PHR CENT. }\end{array}$ & $\begin{array}{l}\text { ONE-THIRD INCH } \\
\text { IN DIAMETER; } \\
\text { FREQUENCY IN } \\
\text { PER CENT. }\end{array}$ & $\begin{array}{l}\text { ONE NINTE INCH } \\
\text { IN DIAMETER; } \\
\text { FREQUENCY IN } \\
\text { PER CENT. }\end{array}$ \\
\hline 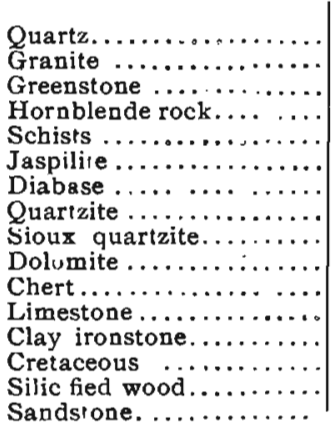 & $\begin{array}{r}2 \\
10 \\
5 \\
0 \\
5 \\
2 \\
26 \\
2 \\
3 \\
5 \\
3 \\
33 \\
2 \\
2 \\
0 \\
\ldots\end{array}$ & $\begin{array}{r}3 \\
13 \\
2 \\
0 \\
2 \\
0 \\
17 \\
4 \\
1 \\
8 \\
5 \\
42 \\
1 \\
2 \\
1 \\
\ldots\end{array}$ & $\begin{array}{r}10 \\
15 \\
1 \\
2 \\
1 \\
0 \\
10 \\
2 \\
1 \\
5 \\
6 \\
44 \\
0 \\
3 \\
0 \\
1\end{array}$ \\
\hline
\end{tabular}

At the foot of the loess bluffs northwest of Hamburg a loesslike talus was seen in which with occasional land snails some broken valves of a unio were noted. Such loess has also been observed by Professor Shimek east of Hamburg and it probably represents material which has been formed comparatively recently. The same may be said of some loess in the vicinity of Glenwood, where ancient potsherds have been found several feet. under the surface on low uplands.

The fossil snails of the loess are not quite as numerous as in Pottawattamie county. The collections which the present writer made have been submitted to Professor Shimek, whose report on these and on others collected by himself in this part of the state

-Compare Iowa Geol, Burv. Vol. XI, p. 259.

12 G Rep 
is appended. In two places vertebrate remains kave been discovered. Bones of a mammoth were exhumed from the lower part of the loess at Malvern in grading for the Chicago, Burlington and Quincy railroad. The excavation was made in 1879 on lot 327, at the crossing of First avenue and Railway street. There were three teeth, part of a tusk an 3 two long bones. The other locality is in the southernmost point of the bluffs between Keg creek and the Missouri bottoms; enst of Pacific Juncticn. In grading the railroad some bones of an elephant or of a mastodon were unearthed near the base of the loess. As fossils of the loess must perhaps also be included occasional potsherd and fint implements, which have been noted in the vicinity of Glenwood. They are reported to have been taken out from a few feet below the surface on some upland slopes and ridges and they are of interest as indicating a recent origin of the upper part of the loess deposit.

REPORT BY PROFESSOR B. SHIMEK ON THE FOSSILS FROM THE LOESS OF MILLS AND FREMONT COUNTIES.

Professor Udden submitted six collections of fossils for examination. Three of these are from Mills county, and three from Fremont county. The writer of this supplementary report also collected fossils in several localities in and near Hamburg, in Fremont county. The several lists follow:

1. From base of loess in bluff of Kelly creek, one quarter mile south of Glenwood, Mills county. Professor Udden.

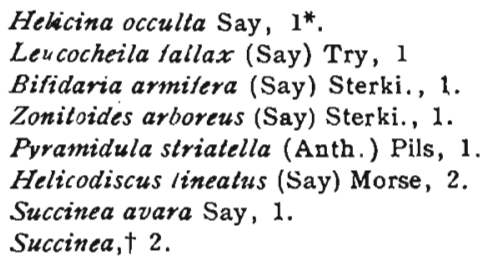

2. Exposure three miles south of northeast corner of section 31, Oak township, Mills county. Professor Udden.

\footnotetext{
* These numbers indicate number of specimens collected of ench specles.

tThese collections contain a number of larger Buccinens, some of which are certainly $\$$. ovalks Say 'commoniy known as $\boldsymbol{S}$. obliqua) and others quite as clearly $\boldsymbol{S}$. grosvenorii Lea. There are, however, small or broken specimens which cannot readily be separated, and they are hare reported_collectively as Succinea.
} 
Helicina occulta Say, 1.

Vallonia gracilicosta Reinb, 2.

Bilidaria pentodon (Say) Sterki, 1.

Pyramidula slriatella (Anth.) Pils, 9.

Pyramidula shimekii (Pils) Shimek, 2.

Succinea avara Say, 3.

Succinea, 7.

3. Base of loess, Missouri river bluffs one-half mile south of Henton, Mills county. Professor Udden.

Helicina occulla Say, 4.

Poligyra leai (War8) .Pils, 2.

Vilrea hammonis (Strom), Pils 1 .

Pyramidula allerternala (Say) Pils, 2.

Pyramidula sirintella (Anth.) Pils, 1.

Succinea, 1 .

The remaining specimens are from the following Fremont county localities:

4. Terraces (?), base of Missouri river bluff near north line of northeast quarter, section 2, Scott township. Professor Udden.
Polygyra mullilineata (Say) Pils, 5.
Zonitoides arboreus (Say) Sterki, 1.
Pyramidula alternata (Say) Pils, 1.
Pyranidula slrialella (Anth.) Pils, 1.
Helicodiscus lineatus (Say) Morse, 1.
Succinea relusa Lea,? 1.
Limnca humilis Say, 1.

5. Base of Missouri river bluffs, west of Hamburg. Professor Udden.

Helicina occulta Say, 1.

Helicodiscus linealus (Say) Morse, ${ }^{*} 1$.

Succinea avara Say, 5.

Succinea, 7.

6. Exposure in northeast quarter, section 6, 'Washington township. Professor Udden.

Helicina occulla Say, 7.

Vallonia gracilicosta Reinh, 1.

Pyramidula strialella (Antb.) Pils, 4.

Pyramidula shimekii (Pils) Shimek, 1.

Helicodiscus lineatus (Say) Morse, 1.

Succinea avara Say, 2.

Succinea, 7 .

A snail's egg appearing like that of Pyramidula striatella.

\footnotetext{
- This appears to be a modern blenched shell.
} 
The writer's collections were made in the years 1890 and 1898 in the immediate vicinity of Hamburg, Fremont county. The several lists, with brief discussions of localities, follow:

7. An exposure in the brickyard east of the Nishnabotna river contained fragments of Unios only one of which, Obliquaria reflexa Raf. (formerly known as Unio cornuti) was identifiable. The deposit was only a few feet above the river, and showed evidences of redeposition. Two small exposures near the brickyard, and but little higher, contained the following fossils:

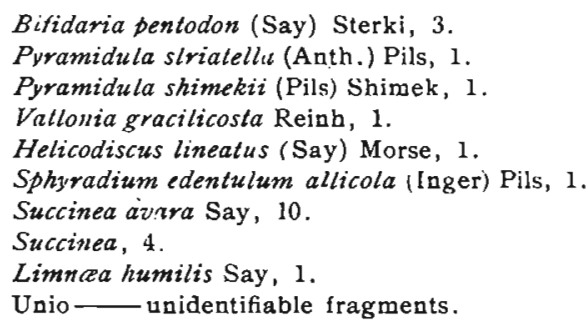

As noted, these deposits are but little elevated above the river, and are not typical upland loess.

8. An exposure at the base of the Missouri river bluff northwest of Hamburg. This exposure was but little elevated above the broad Missouri river plain, resembling No. 7 in this respect.

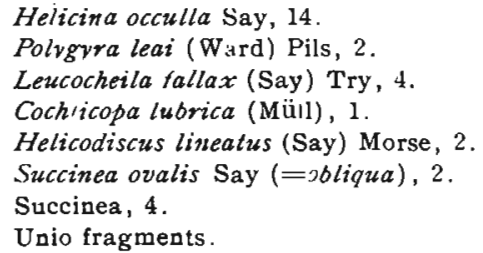

9. A great loess-covered ridge extends southward between the Nishnabotna and Missouri valleys, and terminates abruptly in Hamburg. Near its southern extremity, at a point about thirtyfive feet above the river plain, near the schoolhouse, an exposure yielded the following fossils:

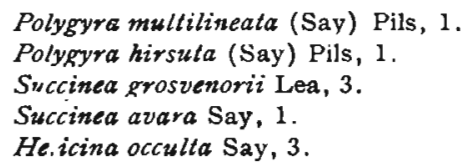


10. An exposure at the top of the Hamburg ridge about 150 feet above the river plain. The ridge is fully exposed on the south and west to the winds which sweep across the broad valley of the Missouri river, and its materials in this exposure show a considerable admixture of fine sand. The fossils which were obtained by digging are here listed.

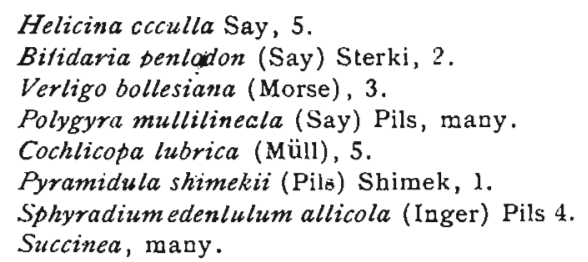

In addition to these numerous other specimens were piled up on the surface. Some of these may be loess fossils, but most of them are clearly modern shells. They are the following:

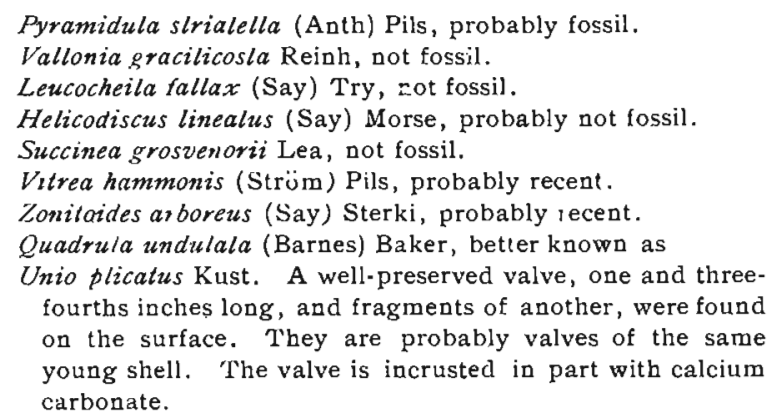

It is interesting to note that these recent species are all represented in the loess of the same region, with the exception of the Unio, which, of course, did not live on the ridge, but was brought to it from one of the adjacent streams.

The occurrence of fluviatile bivalves in some of these exposures is of interest. It will be noted, however, that in every case the exposure is low, within easy reach of flooded adjacent streams. Some shells are frequently embedded in ice, and during floods in the spring are deposited above the ordinary level of the stream. Moreover, muskrats frequently carry mussels to some distance from the water. The writer has seen a crow carry a small mussel to a point more than fifty feet above the Iowa river. The presence 
of these shells, few in number and at low levels in deposits which have been subject to overflow, add's nothing in support of the theory that the main body of the loess was formed in water. A similar mussel-bearing deposit at Sioux City has been known for some time. At both localities the deposit is unlike ordinary upland loess, and has probably been re-arranged by water. No mussel-shells were found in the collections submitted by Professor Udden. However, in the set marked No. 4, which is from a terrace at the base of a bluff, a Limnæa and a specimen of Succinea retusa are found. The first is a pond snail, the second, not satisfactorily identified in its fragmentary condition, a marsh species. Both now live in the region, and neither indicates general aquatic conditions. It will also be observed that one specimen of Limnæa was also found in the brickyard exposure, No. 7, associated with the mussel fragments.

All the remaining species in the several lists are strictly terrestrial, of the usual type found in the loess, and with three exceptions the species now live in the bluff region between Council Bluffs and Hamburg, as the writer has ascertained by personal investigation and as noted, some are now found on the Hamburg ridge. The three exceptions are Helicina occulta, Pyramidula shimekii and Sphyradium edentulum alticola. These are all up. land terrestrial species, now living in other parts of the country, and the two latter belong to the dry western regions. Where any of these terrestrial species show variation from ordinary easterly types, it is of the same charter as that exhibited by the modern - shells of the same region. For example, Polygyra multilineata as found in loess of the region under discussion, is the small, rather heavy, coarsely ribbed form, often without color-bands and fine revolving lines, which commonly occurs in the west in open or upland country. The Succineas are also of the smaller westerly type. Valtonia gracilicosta is a western upland species.

The inevitable conclusion drawn from these fossils is that the deposit in which they are imbedded was formedl under conditions not materially different from those which prevail in the same region today. That the amount of material carried by winds is sufficient for the formation of such a deposit was amply demonstrated, not only during the two visits to Hamburg, but upon every 


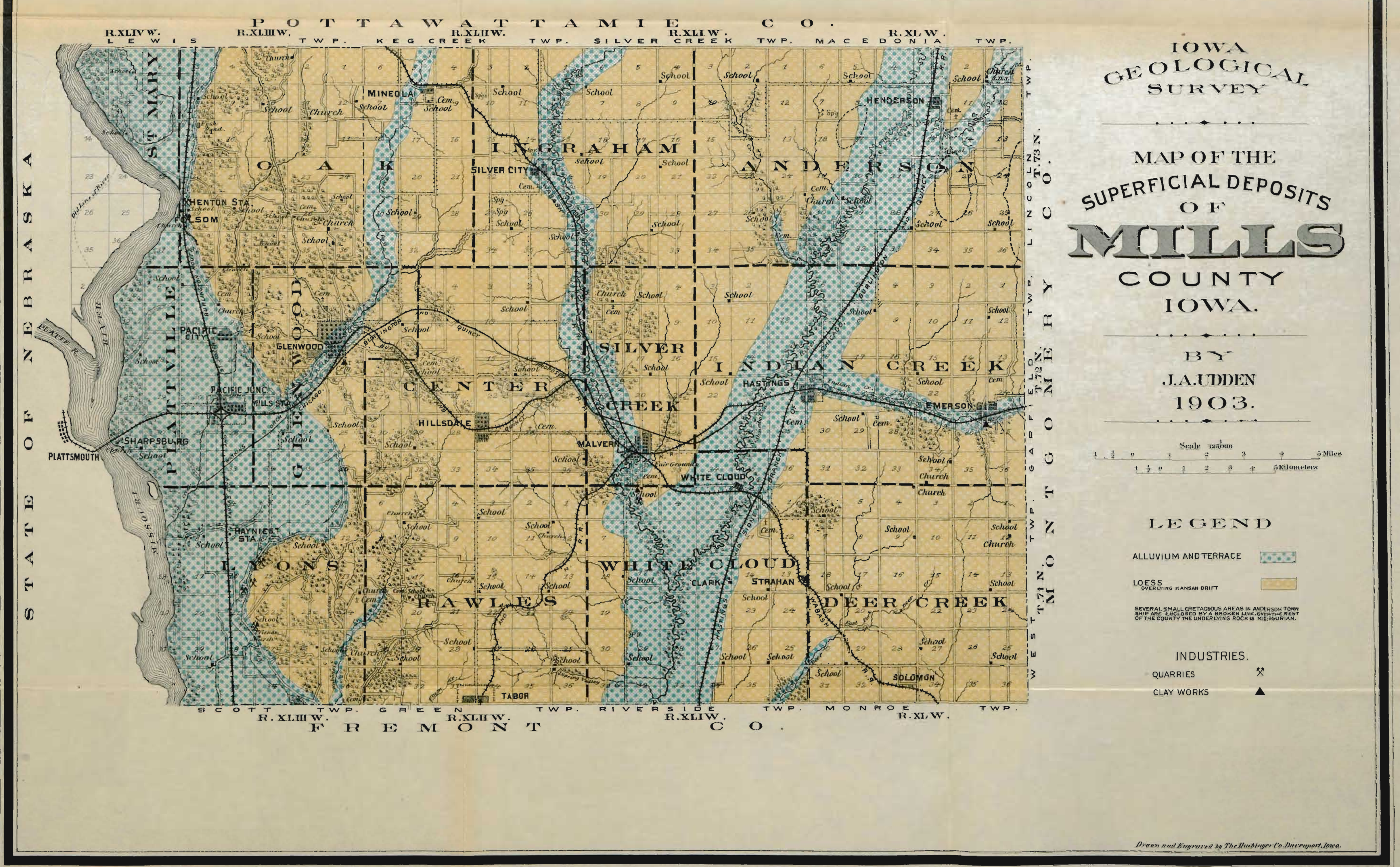


one of the numerous summer and autumn excursions which the writer has made to the Missouri river in Iowa and Nebraska. Dher storms which blot out the landscape by the mass: of whirling, blinding dust are common, and even ordinary winds carry columns of dust from the sand and mud bars of the Missouri to heights far above the bordering hills. During the low water stage in summer and autumn the bars are of great extent and contribute large quantities of fine materials to the adjacent bills, where they are retained by the vegetation which covers the hills.

In the light of the evidence furnished by the fossils it is useless to search for causes and means of loess deposition which would postulate conditions differing in any important particular from those which now prevail in the Missouri river region.

The Alluvium.-Though the alluvium deposits are extensively developed in the drainage valleys opportunities of studying: exposures of their deeper parts are wanting. The material which appears in the stream banks is mostly fine yellow silt, evidently derived mainly from the upland loess, with some sandy layers at distant intervals. Often the upper four or five feet consist of a black muck on the larger flood plains. But the alluvium extends considerably below the beds of the streams and at greater depths contains layers of sand and gravel as well as beds of old soils now buried under from twenty to thirty feet of the more recent alluvium. In the west part of Thurman such an old soil is frequently found in digging wells. On the bottom lasids in the East Nishnabotna well makers report going through a few feet of black soil and below this about twenty feet of yellow clay silt. Below this there is some five or ten feet of fine quicksand and about fifteen feet of blue clay, under which is a white or gray sand, of ten with some gravel. The latter usually contains water. This succession may be regarded as typical of the bottoms of both of the Nishnabotna rivers. In the bottoms of the Missouri river the alluvium is known to have a depth of not far from eighty feet farther north, and it probably has the same depth here. Where the bluffs recede from the river and the bottoms have not been subject to destruction and reconstruction by recent meanders low alluvial fans have in many places been built up by the streams which come down from the uplands and there 
may be a gradual rise of the alluvial plain toward the bluffs of as much as thirty or even forty feet. In one of these alluvial fans near the village of Knox charred wood and some animal bones were once found in an old soil at a depth of about twentyfive feet under the present surface.

Calcareous Tufa.-Some heavy deposits of calcareous tufa have been formed in the base of the bluffs of the Missouri. One of these deposits occurs near the county line along the road east and north of Buckingham lake.' It forms a bed some five feet thick and lies on a gravelly silt. In places it is impregnated with wad, which makes it almost black. In constructing the road it has been broken up into large blocks' which have been thrown aside. The other locality is a little southeast of the center of section 10, Lyons township, Mills county, where large springs issue from under the drift, here resting on the Coal Measures. A mass of coarse tufa eight feet high runs for a distance of about 200 feet along the foot of the bluff. Some tufa was also found in a ravine east of Wabonsie lake and this contains fine imprints of leaves. It is hardly necessary to add that all of these deposits were very recently formed by water's issuing: from the drift back of the place where they now lie, and that in some instances they are still forming.

\section{Geological Structure.}

If the writer's correlations of the ledges of the Missourian are correct there is a gentle general dip to the south of not more than three feet per mile. Probably there is also a similar dip to the west. The evidence is not conclusive. In some shales in a ravine in the northeast quarter of the northeast quarter of section 24, Tp. 67 N., R. XLII W., two sharp but small folds were observed involving a few feet of the rock in such a way as to produce two overthrusts. These were a few rods apart.

\section{Scorings.}

Scorings made by the ice which deposited the bowlder clay have been noted in this territory by Professor Todd. The present writer observed some additional scorings not previously recorded. One locality is near the southeast corner of section 22 in Glenwood township, Mills county, about 150 feet southwest 
of the bridge across Keg creek. They are seen on a low ledge of limestone in the west bank of the creek and run S. $12^{\circ} \mathrm{W}$. and S. $14^{\circ} \mathrm{W}$., with a length of about forty feet. On top of the limestone in the bluffs in sections 10 and 15 in Lyons township, Mills county, scorings are frequent. Their bearings were noted in several places as follows: S. $29^{\circ}$ W., S. $34^{\circ}$ W., S. $33^{\circ}$ W., S. $25^{\circ}$ W., S. $29^{\circ}$ W., S. $27^{\circ}$ W. On a ledge of rock which is now concealed, in the south bank of Spring Valley creek a little south of the center of the south line of section 36 in Rawles township, Mills county, fine planing and scoring was observed many years ago by the quarrymen and some specimens are found on rocks taken from the quarry at this place. The striations are said by a man who worked in the quarry to have a northeast-southwest trend.

A most peculiar instance of scorings on the upper surface of a black shale was observed at a small quarry about one-half mile south of Henton in the base of the bluffs. The shale is the up. permost of the Missourian at this place and is overlain by a discontinuous, thin layer of bowlder clay on top of which loess rests. A finely striated horizontal plane separates the bowlder clay and loess from the shale and the striæ bear S. $7^{\circ} \mathrm{W}$., straight for several feet. A hundred feet to the north the same shale is cut by a shearing plane almost as perfectly planed and scored, the strix running $\mathrm{S} .50^{\circ} \mathrm{W}$. This plane is gently inclined to the west.

\section{ECONOMIC PRODUCTS.}

\section{Building Stone.}

Building stone is scarce in this region and most of that used is at present imported. There are nevertheless a few quarries from which considerable rock may yet be taken out. The largest is in section 16, Lyons township, Mills county, in the bluffs of the Missouri river. The limestone ledges at this place have already been sufficiently described. The lower ledges furnish a strong and durable building stone which was formerly extensively quarried and used in the construction of bridge piers and in riprapping embankments of railroads along the river. Several acres of the ledges were removed, but as the face of the 
quarry receded the stripping became more expensive and quarrying on a large scale was abandoned several years ago. This illustrates the condition of almost all the quarries in both connties. The most easily worked ledges have been removed and those which remain require heavy stripping before they can be quarried. The sandstone of the Cretacecus south of Henderson is a strong and durable building. stone and it seems that some of these ledges might be worked quite inexpensively. At present quarries are operated only occasionally in these counties.

\section{Coal.}

The seam of coal which appears in the bluffs east of lake Wabonsie and in the uplands east of Hamburg is reported as having been twenty inches thick in one exploration pit in section 1, Tp. 67 N., R. XLII W. It is of a good quality and lies near the surface. It does not seem improbable that some workable pockets may be found under the unlands northeast of Hamburg, and pos'sibly also, on the west side of the Nishnabotna river, but as the seam lies above the general level of the eroded surface of the Coal Measures it is certain to run out against the overlying dri.t and be absent on most of the land. As the seam is thin and as most of it has been washed away explorations must be expected to meet with failure in most instances.

\section{Clay Industries.}

The production of brick in Fremont county amounts to about four million and in Mills county to nearly two million in a season, eight firms being engaged in this industry in the former and three everywhere the material used. Mr. C. W. Carman, at the latter place, uses a leached shale from the Coal Measures in various proportions with the loess. Mr. T. S. Hall of Glenwood is the in the latter county. Excepting one firm in Hamburg, loess is only maker of bricks used for paving and these are loess bricks, burnt hard and culled from the common. Open kilns are used in all the yards and Missouri coal is the fuel most generally employed. Very little of the product is exported. The detailed statements for each manufacturer are given in the following table. 
CLAY INDUSTRIES.

\begin{tabular}{|c|c|c|c|c|c|c|c|c|}
\hline $\begin{array}{l}\text { NAME OF NWNER AND } \\
\text { IOCATTON. }\end{array}$ & CLAY UZEED. & HOW DRIED. & $\begin{array}{l}\text { OPEN } \\
\text { KILNS. }\end{array}$ & $\begin{array}{l}\text { QUANTI IY } \\
\text { OF PRODUCT } \\
\text { - COMMON } \\
\text { BRIOK. }\end{array}$ & $\begin{array}{l}\text { NUMB R } \\
\text { OF MEN } \\
\text { EMP'YD. }\end{array}$ & $\begin{array}{l}\text { KXX D OF } \\
\text { MACHUNR. }\end{array}$ & (estimatid) & REMARKS. \\
\hline $\begin{array}{l}\text { c. W. Carman, Hamburg ..... } \\
\text { Fred Johnson, Hamburg...... }\end{array}$ & $\begin{array}{l}\text { Loess and shale.. } \\
\text { Loess. ............. }\end{array}$ & $\begin{array}{l}\text { Shed dried. } \\
\text { Shed dried. }\end{array}$ & $\begin{array}{l}5 \\
3\end{array}$ & $\begin{array}{r}1,0<0,000 \\
5 \subset 0,0<0\end{array}$ & $\underset{7}{10}$ & $\begin{array}{l}\text { Quaker soft mud. } \\
\text { Hand made. .... }\end{array}$ & $\begin{array}{r}\$ 5,500.00 \\
2,750.00\end{array}$ & \multirow{6}{*}{$\begin{array}{l}\text { Town and country market. } \\
\text { Market: home and other } \\
\text { towns. } \\
\text { Town and country. } \\
\text { Mayket: home, country } \\
\text { and surround ing towns. } \\
\text { Market: lo me, other towns } \\
\text { and country. } \\
\text { Town and count } \\
\text { Home market. } \\
\text { Howe market. } \\
\text { Home market. } \\
\text { Hone market. } \\
\text { Used at the ingtitution. }\end{array}$} \\
\hline $\begin{array}{l}\text { A. E. and A P. Brown, Hamburg } \\
\text { John Johnson, Riverton ............ }\end{array}$ & Lóess............... & $\begin{array}{l}\text { Sun dried } \\
\text { Sned dried. }\end{array}$ & $\begin{array}{l}2 \\
3\end{array}$ & $\begin{array}{l}500,000 \\
400,000\end{array}$ & $\begin{array}{l}\text { G } \\
B\end{array}$ & $\begin{array}{l}\text { Anderron's Chief } \\
\text { isand made....... }\end{array}$ & $\begin{array}{l}2,75000 \\
2,400.00\end{array}$ & \\
\hline X. Stone, Malvern .............. & Loess and soil.... & Shed dried. & 3 & 800,000 & 10 & Sells. & $6,400 . \mathrm{CO}$ & \\
\hline \multirow{3}{*}{ 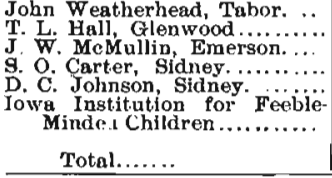 } & $\begin{array}{l}\text { Loess. .. ......... } \\
\text { Loess. } \\
\text { Loess wash. ........ } \\
\text { Loess ............... } \\
\text { Loess ............ }\end{array}$ & $\begin{array}{l}\text { Shed dried. } \\
\text { Shed dried. } \\
\text { Sun dried } \\
\text { Sun dried } \\
\text { Shed dried. }\end{array}$ & $\begin{array}{r}3 \\
\\
2 \\
1 \\
1 \\
\ldots \quad . .\end{array}$ & $\begin{array}{l}800,000 \\
850,000 \\
200,000 \\
80,000 \\
2000,000\end{array}$ & $\begin{array}{r}10 \\
5 \\
3 \\
3 \\
3 \\
3\end{array}$ & $\begin{array}{l}\text { Sells } \ldots . . . \\
\text { Machine ?......... } \\
\text { Hand made...... } \\
\text { Soft nud....... } \\
\text { Hand made....... }\end{array}$ & $\begin{array}{l}4,500.00 \\
5,950.00 \\
2,100.60 \\
2,450.00 \\
1,400.60\end{array}$ & \\
\hline & Loess. . .......... & Sun dried.. & 2 & 800,100 & 5 & Banch made........ & $4,000.00$ & \\
\hline & & $\ldots$ & 24 & $8,0 \circ 0,0<0$ & 68 & & $\$ 40,200.00$ & \\
\hline
\end{tabular}




\section{Water Supply.}

On the uplands, which are every where well drained, the natural water supply is now becoming more limited than before owing to the general lowering of the level of the ground water. In the base of the loess there is always some seepage, but this cannot be relied upon to furnish a sufficiency for most farmers, and wells are now sunk into the underlying bowlder clay. But this seldom contains sandy strata pervious to water and such wells frequently must be made deep: enouglı and wide enough to catch sufficient seepage from the compact and impervious clay. Occasionally these deep wells go through the drift and draw water from the underlying bed rock. In the northeast part of Mills county there is a sandstone in some wells and these furnish plenty of good water. But over most of the upland the bed rock consists of Coal Measure shales with thin ledges of limestone and on such land even deep wells have proved failures. Deep and wide bored drift wells will probably prove to be most serviceable, and tributary tunnels will no doubt prove useful, where they can be bored out and tiled from the bottom of the main excavation.

On the alluvial bottoms there is always water at moderate depths, varying from ten to fifty feet and driven wells are in general use. Near Riverton an attempt was made some years ago to secure flowing water from shallow. wells on the Nishnabotna bottoms, but it resulted in failure, though three holes were sunk to a depth of about 300 feet. A flowing well was unexpectedly obtained near the center of the northwest quarter of section 14 in Anderson township, Mills county. It was made near the foot of the west slope of Mud creek and the water came from a sand under a blue "shale" at a depth of about 200 feet. The head of the flow is forty feet above the curb. The flow was nearly a barrel a minute. It is probable that the sand in the bottom of this well is an outlier of the Cretaceous sandstone.

The conditions for deep artesian wells have been sufficiently discussed by Professor Norton.* Since his paper was published another deep well has been made loy the Institute for Feeble Minded Children at Glenwood. $\Lambda$ rtesian flow can be obtained at a depth of about 2,000 feet on all lowlands not rising higher than about 950 feet above the sea level.

-Artesian Wells of Iowa, Iowa Geol. Surv., VoI, VI, pp. 340 34i, 
STATICTICS ON PUBLIC WATERWORKS.

\begin{tabular}{|c|c|c|c|c|c|c|c|c|c|c|c|}
\hline LOOATION. & BOURCE OF WATER. & 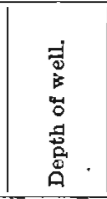 & 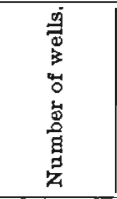 & 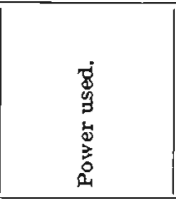 & 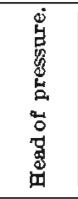 & 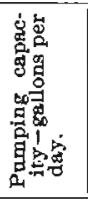 & 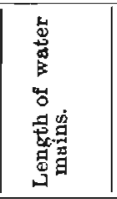 & 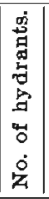 & 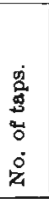 & 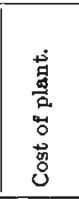 & 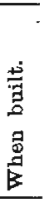 \\
\hline 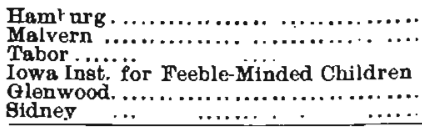 & 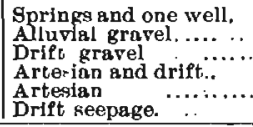 & $\begin{array}{r}25 \mathrm{ft} . \\
40 \mathrm{fr} \\
20 \mathrm{ft} \\
191-300 \mathrm{ft} \\
2,014 \mathrm{ft} . \\
50 \mathrm{ft}\end{array}$ & $\begin{array}{l}1 \\
27 \text { points. } \\
\cdots \\
2 \\
1 \\
1 \\
\end{array}$ & $\begin{array}{l}1 \text { stram pump } \\
1 \text { steam pump.. } \\
2 \text { steam pumps. } \\
1 \text { steam pump. } \\
1 \text { gt eam pump.. }\end{array}$ & $\begin{array}{l}170 \mathrm{ft} . \\
120 \mathrm{ft} . \\
\cdots 0 \mathrm{ft} . \\
00 \mathrm{ft} . \\
70 \mathrm{ft} .\end{array}$ & $\begin{array}{r}400,000 \\
200,000 \\
05,000 \\
100,000 \\
80,000\end{array}$ & $\left|\begin{array}{ccc}11 / 2 & \text { miles } \\
2 & \text { miles. } \\
3 / 4 & \text { mile. } \\
21 / 2 & \text { miles } \\
2 & \text { m les }\end{array}\right|$ & $\begin{array}{l}25 \\
15 \\
12 \\
19 \\
18\end{array}$ & 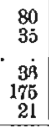 & $\begin{array}{r}\$ 4,000 \\
8,000 \\
30,000 \\
15,000 \\
10,000\end{array}$ & $\begin{array}{l}1891 \\
18902 \\
* \\
1896 \\
1892 \\
\cdots\end{array}$ \\
\hline
\end{tabular}




\section{Sand and Gravel.}

Sand for mortar and plaster is taken mostly from the beds of the streams, where it is by no means plentiful except in the Missouri. An extensive gravel and sand pit was worked for several years by the railroad in the bluffes of the Missouri river near the center of section 32, a mile sonth of Henton station, but this pit is now abandoned except for local demand. It is a glacial sand which in places has been cemented by infiltration of calcareous material into rock strong enough to be used in small foundations. Another sand pit supplies a local demand in Fremont county. This is located in the base of the bluff's east of Percival, near the center of the west line of section 30, Tp. 68 N., R. XLII $W$. This sand is rather fine and is probably of a later age than the bowlder clay.

\section{Soils.}

The wealth of this region is due chiefly to the excellency of the soil, which is for the most part a porous loess or loess wash, with a deep black humus on all the lowlands. Sandy tracts are almost unknown and only of very limaited extent near the channels of the Missouri and Nishnabotna rivers. A few acres of such soil is seen on the south side of the Nishnabotna west of Riverton. In a few places on the upland slopes the red gumbo clay is in evidence, and bakes in dry seasons. The best lands, as being least affected by seasonal variations in rainfall, are the low terrace flats, usually known as the "second bottoms." In dry seasons such land is low enough to draw moisture by capillarity from below and in wet seasons it is high enough and the soil porous enough to allow the superfluous precipitation to sink away into the sandy ground below.

\section{ACKNOWLEDGMENTS.}

For aid in the field: work in these two counties the author is under obligations to his son, Jon Andreas Udden, who gave valuable assistance the entire season, to $\mathrm{Mr}$. Seth Dean of Glenwood for information relative to that locality and to the old Hamburg Fuel and Mining Company for an opportunity to examine the core from their prospect drilling. His thanks are also due 
to Professor B. Shimek, who has examined the fossils from the loess and kindly reported on them, to Dr. Samuel Calvin, Dr. Josua Lindahl, Dr. J. M. Clarke and Dr. Schuchert for aid in identifying fossils and to Dr. Gecrge L. Smith of Shenandoah for some specimens of coal from the Nodaway vein and for notes on the geology of that region. Dr. E. Schellwein, of Königsberg, Germany, has kindly examined and reported on several samples containing Foraminifera. 
